\title{
Buckwheat Yield Traits Response as Influenced by Row Spacing, Nitrogen, Phosphorus, and Potassium Management
}

\author{
Ljubiša Kolarić ${ }^{1}$, Vera Popović ${ }^{2, *}$, Ljubiša Živanović ${ }^{1}$, Nataša Ljubičić ${ }^{3}{ }^{\circledR}$, Petar Stevanović ${ }^{4}$, \\ Ljubica Šarčević Todosijević ${ }^{5}$, Divna Simić ${ }^{6}$ and Jela Ikanovićc ${ }^{1,7}$ \\ 1 Faculty of Agriculture, University of Belgrade, 11080 Belgrade, Serbia; kolaric@agrif.bg.ac.rs (L.K.); \\ ljuba@agrif.bg.ac.rs (L.Ž.); jela@agrif.bg.ac.rs (J.I.) \\ 2 Institute of Field and Vegetable Crops, 21000 Novi Sad, Serbia \\ 3 Institute of Biosense, University of Novi Sad, 21000 Novi Sad, Serbia; ljubicic.natasa@gmail.com \\ 4 Technical Faculty, Agriculture, European University, Brcko Diskrit, 76100 Brčko, Bosnia and Herzegovina; \\ p.stevanovic@inspektorat.vladars.net \\ 5 High Medical Sanitary School of Professional Studies “Visan”, 11080 Belgrade, Serbia; ljsarcevic@gmail.com \\ 6 Institute for Science Application in Agriculture, 11000 Belgrade, Serbia; simic.divna@yahoo.com \\ 7 Faculty of Ecology, Independent University of Banja Luka, 78000 Banja Luka, Bosnia and Herzegovina \\ * Correspondence: vera.popovic@ifvcns.ns.ac.rs; Tel.: +381-648205733
}

check for

updates

Citation: Kolarić, L.; Popović, V.; Živanović, L.; Ljubičić, N.; Stevanović, P.; Šarčević Todosijević, L.; Simić, D.; Ikanović, J. Buckwheat Yield Traits Response as Influenced by Row Spacing, Nitrogen, Phosphorus, and Potassium Management. Agronomy 2021, 11, 2371. https://doi.org/ 10.3390/agronomy11122371

Academic Editor: Chenggen Chu

Received: 3 November 2021

Accepted: 18 November 2021

Published: 23 November 2021

Publisher's Note: MDPI stays neutral with regard to jurisdictional claims in published maps and institutional affiliations.

Copyright: (c) 2021 by the authors. Licensee MDPI, Basel, Switzerland. This article is an open access article distributed under the terms and conditions of the Creative Commons Attribution (CC BY) license (https:// creativecommons.org/licenses/by/ $4.0 /)$.

\begin{abstract}
Buckwheat is an economically important gluten free cereal, and it is a good source of protein, fiber, and energy. The field experiments with buckwheat variety "Novosadska" were set in two experimental years in Pancevo, Serbia. The aim of this study was to determine the most optimal technology for buckwheat production. The study aims were to investigate the effects of (1) row spacing: $\mathrm{RS}_{1}-25 \mathrm{~cm}$ and $\mathrm{RS}_{2}-50 \mathrm{~cm}$; (2) nutrition variants: $\left(\mathrm{N}_{1}\right) 0 \mathrm{~kg}$ ha ${ }^{-1} \mathrm{NPK} ;\left(\mathrm{N}_{2}\right) \mathrm{NPK}$ $30 \mathrm{~kg} \mathrm{ha}^{-1} ;\left(\mathrm{N}_{3}\right)$ NPK $60 \mathrm{~kg} \mathrm{ha}^{-1}$; and $\left(\mathrm{N}_{4}\right)$ NPK $90 \mathrm{~kg} \mathrm{ha}^{-1}$; (3) environment: $\mathrm{Y}_{1}-2018$ and $\mathrm{Y}_{2}-2019$; and their interactions on the plant height $(\mathrm{PH})$, number of lateral branches (NoLB), mass of seeds per plant (MSP), number of seeds per plant (NoSP), buckwheat grain yield (GY); and (4) the correlations among these traits. All tested parameters of buckwheat significantly varied across row spacing, environment, and nutrition. The average grain yield in the row spacing, $\mathrm{RD}_{1}-25 \mathrm{~cm}$, was significantly higher than in the wider spacing, $\mathrm{RD}_{2}-50 \mathrm{~cm}$, and in 2018 than 2019 as well as with the nutrition NPK applied in the amount of $90 \mathrm{~kg} \mathrm{ha}^{-1}$ in relation with all the other nutrition variants. All the studied agronomic traits were positively and strongly correlated with GY.
\end{abstract}

Keywords: Fagopyrum esculentum; nutrition; row spacing; year; productive traits; correlation

\section{Introduction}

Common buckwheat (Fagopyrum esculentum Moench; $2 \mathrm{n}=2 \mathrm{x}=16$ ) is an allogamous crop, belonging to the family Polygonaceae, which is classified as a pseudo-cereal. It is an important crop in mountain regions. Buckwheat is characterized by a low grain yield despite an abundant of flowers formation through a long period of time [1-4]. Buckwheat grain is rich in nutrients: it contains up to $12 \%$ digestible protein, about $2 \%$ fat, $70 \%$ starch, and $0.5 \%$ sugar. Proteins are represented by glutenins and globulins. The fruits contain citric, oxalic, and malic acids, which are favorable for digestion. It also contains high levels of vitamins B1 and B2, calcium, phosphorus, and iron that are beneficial to humans. It is used as a curative herb or feed for human and animals. The overhead part of the plant in the flower is used in phytotherapy. It contains the flavone heteroside-rutin in the amount of $1.8 \%$ in the fresh leaf, about $0.7 \%$ in the flower, and very little in the stalk. The positive role of flavonoids in the treatment of capillary damage has been observed in the suppression of scurvy $[2,3,5]$. Chlopicka [6] has introduced rutin as the most important flavonoid in buckwheat, and it is estimated as $4-6 \%$.

Alternative cereals, such as plain buckwheat, are of great importance for agriculture. Buckwheat is cultivated for honey because of its positive impact on the soil and for 
obtaining more by-products from it. For bee grazing, it can be sown successively in five terms. Buckwheat can be used as green manure and as plants for erosion control, thus creating a source of income for farmers. It is very popular in developed countries where organic food, produced in organic production, is given great importance. Buckwheat grains are an important source of macro elements such as $\mathrm{K}, \mathrm{Ca}, \mathrm{Mg}$, and $\mathrm{Na}$ as well as micro elements such as $\mathrm{Mn}, \mathrm{Zn}, \mathrm{Se}$, and $\mathrm{Cu}$ [2,3,6-8], and they contain rutin, riboflavin, pyridoxine, thiamine, lysine, methionine, arginine, and threonine $[9,10]$. Buckwheat grain fractions showed a variation in protein content of $4.4-11.9 \%$ in flour and 19.2-31.3\% in bran [11]. Buckwheat has similar protein content as cereals but significantly higher lysine content and a significantly higher biological value of protein compared to cereals. Glamočlija et al. [5] state that buckwheat belongs to so-called calliophilous plants, since it contains $40 \% \mathrm{~K}_{2} \mathrm{O}$ in ash. The average protein content of buckwheat has been varied 12.0-18.9\% [2,12].

Considering the fact that buckwheat has a variety of medical, industrial, and food applications, and in our country and in some other countries [13], it has not been seriously cultivated, it should be grown more extensively in multiple planting systems (summer planting) for commercial goals through seed producing. Many researchers have noticed interactions between the date and pattern of sowing with the suitable development of bushes and their role in order to sustain the soil humidity content [3,14]. Changes of plants connected with patterns of sowing with constant density can alter the conditions for light absorption concerning plant biomass. As we get closer to square and rectangular patterns, the lack of light uniformity in vegetative areas will be reduced, and by that, there may be decreased competition for absorbing the light needed for producing assimilates in leaves and stems. The grain protein content is considerably correlated with the nitrogen used from soil, and it can confirm the necessity of nitrogen fertilizer according to the plants' needs [15]. One of the most important agro-technical factors influencing the yield of grain and enabling farmers to take full advantage of the high production potential of cereals is mineral fertilization, especially nitrogen nutrition $[16,17]$. In intensive plant production, the level of nitrogen fertilization and the date of its application are essential for the attainment of high productivity of plants, supplying good quality yields [18]. Buckwheat's (Fagopyrum esculentum) response to nitrogen depends on the primary nitrogen content of the soil, climatic conditions, and nitrogen additives as well as its addition time [3,19]. The buckwheat variety "Novosadska" is one of the most represented varieties in Serbia. Knowledge of the biological properties of the plant itself and its requirements according to environmental conditions form the basis of the cultivation technology. The important agro-technical measures in buckwheat production are nutrition and row spacing [4,19]. Optimizing harvestable buckwheat grain yield requires matching the buckwheat genotype with optimal agro-technical practices $[2,20]$. A crop will express its full potential only when it is backed up by good agronomic practices. Optimum row spacing and plant density provide conditions for proper light interception throughout the crop growth period. Plant density has important effects on the vegetative and reproductive development of buckwheat [10]. Buckwheat yield is low if the density of plants is low [1,19,20]. All these factors influence the crop growth, seed yield, and quality parameters. Nutrients are important and crucial elements, which are required for the plant for its growth and development. The translocation of photosynthates from the source through the plant is very important for the development of those parts of the plant that are important for the economy.

Row spacing, sowing date, and nitrogen greatly influence the amount of fat, starch, protein content, and seed yield. There was an evident influence of row spacing and $\mathrm{N}$ nutrition increase on the protein content $[5,15]$.

The aim of this research was to determine the most optimal technology for buckwheat production, including quantities of nutrition and the method of row spacing (in narrow or wide rows), to produce the highest buckwheat yields. Wide and narrow row spacing are recognized as good management practices in crop production. Optimizing nutrition and row spacing in order to maximize profitability is of great importance in the future buckwheat production in Pannonian environments. 


\section{Materials and Methods}

In order to investigate the influence of the rows spacing and NPK nutrition on the morphological and productive traits of buckwheat, experiments were conducted during

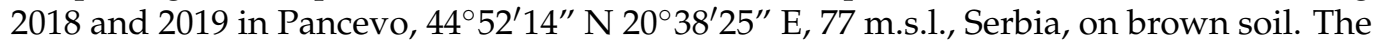
subject of the study was the variety Novosadska, which was selected at the Institute of Field and Vegetable Crops, Novi Sad. The size of the basic plot was $6 \mathrm{~m}^{2}$ for sowing in $25 \mathrm{~cm}$ and $50 \mathrm{~cm}$. The experiment was laid out in a split plot design with three replications having two row spacings $\left(\mathrm{RS}_{1}-25 \mathrm{~cm}\right.$ and $\mathrm{RS}_{2}-50 \mathrm{~cm}$ ) as the main plots and four nutrient levels $\left(\mathrm{N}_{1}-0\right.$ NPK kg ha ${ }^{-1}, \mathrm{~N}_{2}-30$ NPK kg ha ${ }^{-1}, \mathrm{~N}_{3}-60$ NPK kg ha ${ }^{-1}$, and $\mathrm{N}_{4}-90$ NPK $\mathrm{kg} \mathrm{ha}^{-1}$ ) as sub plots. A standard agro-technical measures was applied.

The sowing of buckwheat should be done at a $25 \mathrm{~cm}$ and $50 \mathrm{~cm}$ row spacing, with the consumption of about 60 and $40 \mathrm{~kg}$ of seeds/ha [21]. The crop was watered three times with $30 \mathrm{~L}$ of water in April, May, and June. The crop preceding buckwheat in both years was winter wheat. The basic tillage was done in the autumn, and secondary tillage was done just before the sowing. Manual sowing was done in mid-April, when the planned nutrients were introduced; 4 rows of $3 \mathrm{~m}$ length, in each variant, were sown. Other crop management practices were carried out in accordance with local agronomic practices. Crop was harvested at the stage of technological maturity. Other agro-technical measures were carried out in accordance with local agronomic practices. Crop was harvested at the stage of technological maturity. From all nutrition variants and row spacing, 10 plants were taken from two middle rows for laboratory analyses of morphological and fertility traits. For the morphological traits, the plant height and the number of lateral branches per plant were studied; then, for the fertility traits, the number of seeds per plant and seed mass per plant were analyzed as well as yield as a productivity indicator. Grains from single plots were cleaned, dried, and the weight was recorded. Grain yield was measured in each experimental plot separately and adjusted to $13 \%$ of moisture, and the yield per hectare was recalculated.

\subsection{Soil Conditions}

Plant yield strongly depends on the soil conditions in which the root system develops. The quality of soil conditions is defined by the favorable water-air regime, mechanical composition, and supply of soil nutrients [22-31]. The soil in the experimental plot had, at depths of $0-30 \mathrm{~cm}$ and $30-60 \mathrm{~cm}$, a low alkaline and neutral reaction $\left(\mathrm{pH}\right.$ in $\mathrm{H}_{2} \mathrm{O}=7.01$ and 6.50). There was carbonate ( $7.20 \%$ and $6.61 \%)$ well provided with humus $(3.69 \%$ and $3.40 \%)$, phosphorus (26.30 and $20.11 \mathrm{mg} / 100 \mathrm{~g}$ soil) and potassium (28.90 and $23.70 \mathrm{mg} / 100 \mathrm{~g}$ soil); see Table 1.

Table 1. Chemical composition of the brown earth type of soil in Pancevo, Serbia.

\begin{tabular}{ccccccc}
\hline Parameter & \multicolumn{2}{c}{$\mathbf{p H}$} & Humus & $\mathrm{CaCO}_{3}$ & $\mathbf{P}_{\mathbf{2}} \mathbf{O}_{\mathbf{5}}$ & $\mathbf{K}_{\mathbf{2}} \mathbf{O}$ \\
\hline Depth $(\mathbf{c m})$ & $\mathbf{H}_{\mathbf{2}} \mathbf{O}$ & $\mathbf{K C l}$ & $\mathbf{( \% )}$ & $\mathbf{( \% )}$ & \multicolumn{2}{c}{$\mathbf{m g} / \mathbf{1 0 0} \mathbf{g}$ Soil } \\
\hline $1-30$ & 7.01 & 6.77 & 3.69 & 7.20 & 26.30 & 28.90 \\
$30-60$ & 6.50 & 6.10 & 3.40 & 6.61 & 20.11 & 23.70 \\
\hline
\end{tabular}

\subsection{Meteorological Data}

Meteorological data regarding temperature and precipitation are very variable. Climate change significantly affects crop production [2,32]. During the survey, meteorological indicators were monitored and analyzed: temperatures, amounts, and the schedule of precipitation during the buckwheat vegetation period (Figure 1a,b). Data on monthly precipitation and air temperatures for 2018 and 2019 were taken from the Hydro-meteorological Institute of the Republic of Serbia for Pancevo (Figure 2a,b). The total precipitation in the surveyed years was slightly lower than in the multi-year period (by $18.6 \mathrm{~mm}$ and $5 \mathrm{~mm}$ ), but the order of precipitation was different. The highest precipitation in 2018 and 2019 was recorded in July ( $90 \mathrm{~mm}$ and $93 \mathrm{~mm}$ ), which is $36 \mathrm{~mm}$ and $38.1 \mathrm{~mm}$ higher than the 
average, while in April, May, and August, there was less precipitation than the average. The average daily temperatures in the years studied were slightly higher compared to the multi-year period (by $0.3^{\circ} \mathrm{C}$ and $0.1^{\circ} \mathrm{C}$ ). The highest temperatures in 2018 and 2019 were recorded in August $\left(23.9^{\circ} \mathrm{C}\right.$ and $24.7^{\circ} \mathrm{C}$ ), which is $0.4^{\circ} \mathrm{C}$ and $1.2^{\circ} \mathrm{C}$ higher than the multi-annual average, while in April, June, and July, the temperatures were less than the perennial average, as shown in Figure 1a.

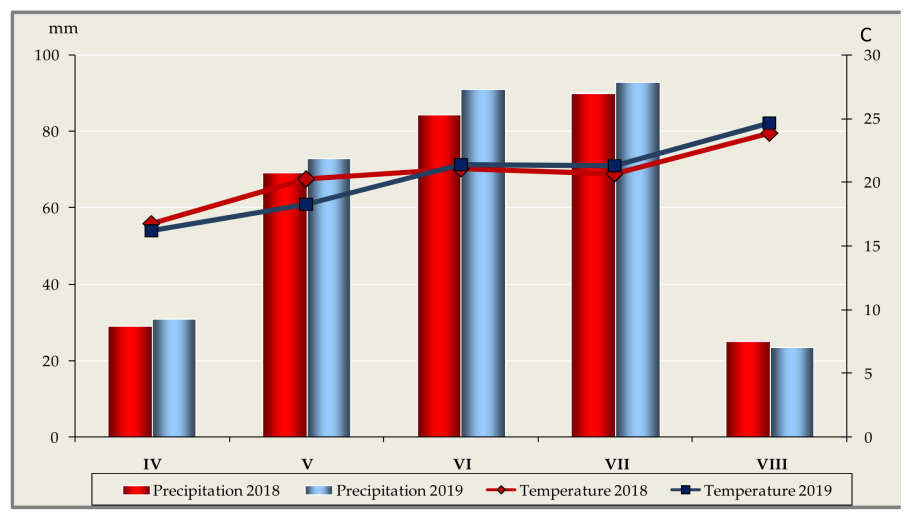

(a)

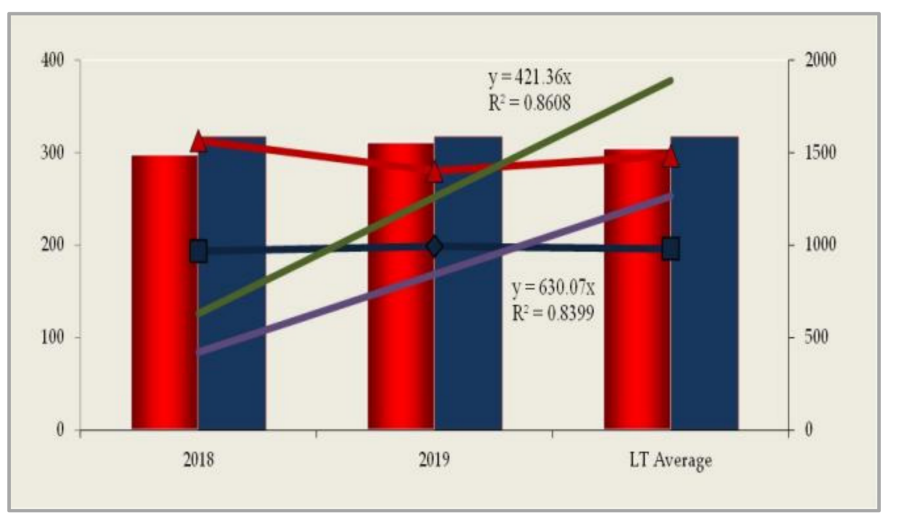

(b)

Figure 1. Temperature $\left({ }^{\circ} \mathrm{C}\right)$ and precipitation (mm) in Pancevo, 2018-2019, Serbia (a); Average grain yield in buckwheat in tested years across the world and in Serbia (b).

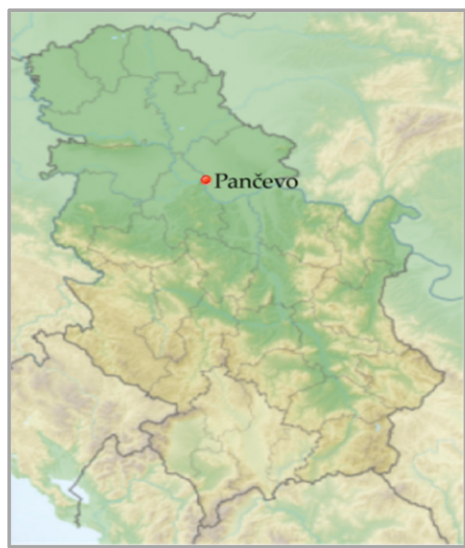

(a)

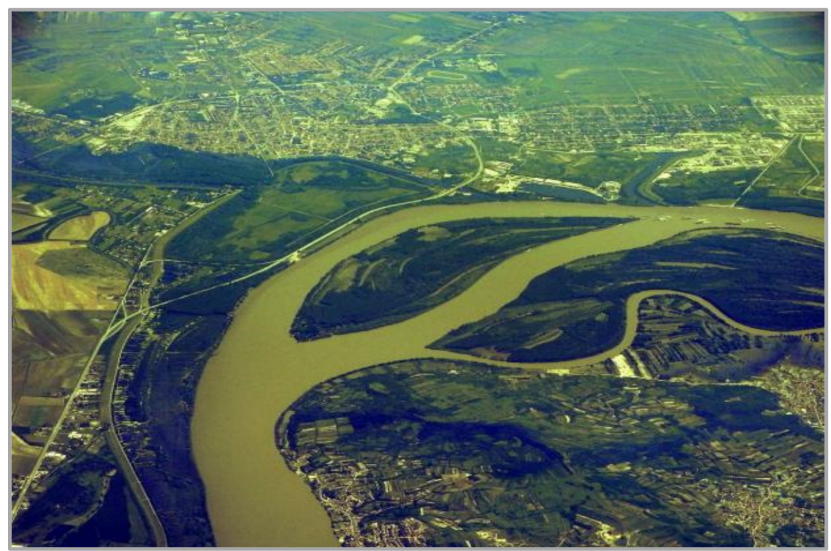

(b)

Figure 2. Locality Pancevo on the map of Serbia (a); Municipality of Pancevo, in the South Banat district, Serbia (b).

A more favorable buckwheat production year was 2018 compared to 2019. In 2018, the total precipitation $(298 \mathrm{~mm})$ decreased by $13.6 \mathrm{~mm}$ and the average temperatures increased by $0.2{ }^{\circ} \mathrm{C}$, but the precipitation schedule and temperature were much more favorable compared to 2019. In May, there was $2.9 \mathrm{~mm}$ less precipitation and temperatures were higher by $2{ }^{\circ} \mathrm{C}$, which led to better initial growth and gave a nice set of plants that overshadowed the weeds with their growth habit.

In August, there were more favorable conditions in 2018; there was $1.8 \mathrm{~mm}$ more precipitation, but temperatures were lower by $1.2^{\circ} \mathrm{C}\left(23.9^{\circ} \mathrm{C}\right)$ compared to $2019\left(24.7^{\circ} \mathrm{C}\right)$, which provided uniform maturing and greater yields.

\subsection{Statistical Analysis}

The experimental data obtained were analyzed using descriptive and analytical statistics using the statistical package STATISTICA 12 for Windows. Significance testing of differ- 
ences between the calculated mean values of the examined factors (years, nutrition variant, and row sowing method) was performed using a three-factor model of variance analysis:

$$
y_{i j k}=\mu+\alpha_{i}+\beta_{j}+\gamma_{l}+(\alpha \beta)_{i j}+(\alpha \gamma)_{i l}+(\beta \gamma)_{j l}+\varepsilon_{i j l k}, i=1,2 ; j=1,2 ; l=1,2,3,4 ; k=3
$$

All significance ratings were based on the F-test and LSD test for significance levels of $0.05 \%$ and $0.01 \%$. The relative dependence was determined by the method of correlation analysis (Pearson's correlation coefficients), and the obtained coefficients were tested by $t$-test for significance levels of $0.05 \%$ and $0.01 \%$.

\section{Results}

The world's current average buckwheat production, in the tested period, was 3,439,088 t. The average area under buckwheat crop in the world in the tested period was 3,499,290 ha and the average buckwheat yield in the world was $981 \mathrm{~kg} \mathrm{ha}^{-1}$, according to the FAO [33]; see Figure 1b. Buckwheat is an alternative crop in the Republic of Serbia. Areas under buckwheat are small, around 150 ha. Nevertheless, buckwheat cultivation is profitable considering its low input requirements.

\subsection{Grain Yield of Buckwheat in Serbia}

The results of 2-year studies of the influence of agro-meteorological conditions on buckwheat grain yield showed that they significantly influence the success in the production of this alternative grain. Average grain yields in Serbia, in the tested year, varied from 1.0 to $1.6 \mathrm{t} \mathrm{ha}^{-1}$ (Table 2, Figure 3a,b).

Table 2. Effect of row spacing ( $\mathrm{cm})$, year, and nutrition variant $\left(\mathrm{kg} \mathrm{ha}^{-1}\right)$ on grain yield $\left(\mathrm{kg} \mathrm{ha}^{-1}\right)$.

\begin{tabular}{|c|c|c|c|c|c|c|c|}
\hline \multirow{2}{*}{\multicolumn{2}{|c|}{$\frac{\text { Parameter/Grain Yield, kg ha }{ }^{-1}}{\text { RS-Row Spacing, cm }}$}} & \multicolumn{2}{|c|}{2018} & \multicolumn{2}{|c|}{2019} & \multicolumn{2}{|c|}{ Average } \\
\hline & & \multicolumn{6}{|c|}{ Average Value \pm Stand. Dev. } \\
\hline \multicolumn{2}{|c|}{25} & 1846 & 371.26 & 1670 & 358.92 & 175 & \pm 368.22 \\
\hline \multicolumn{2}{|l|}{50} & 1284 & 322.35 & 1134. & 222.35 & 120 & \pm 281.47 \\
\hline \multicolumn{2}{|c|}{ Total } & 1565 & 444.50 & 1402. & 400.55 & 148 & \pm 426.84 \\
\hline \multicolumn{8}{|c|}{ NPK levels, $\mathrm{RS}_{1}$} \\
\hline \multicolumn{2}{|c|}{0} & 1354 & 40.46 & 1280 & 40.00 & 131 & \pm 54.47 \\
\hline \multicolumn{2}{|l|}{30} & 1780 & 135.68 & 1386 & 23.09 & 158 & \pm 232.69 \\
\hline \multicolumn{2}{|l|}{60} & 1976 & 108.68 & 1943 & 28.87 & 195 & \pm 73.34 \\
\hline \multicolumn{2}{|l|}{90} & 2274 & 238.17 & 2073 & 30.55 & 217 & \pm 187.68 \\
\hline \multicolumn{2}{|c|}{ Average } & 1846 & 371.26 & 1670. & 358.92 & 175 & \pm 368.21 \\
\hline \multicolumn{8}{|c|}{ NPK levels, $\mathrm{RS}_{2}$} \\
\hline \multicolumn{2}{|c|}{0} & 958 & 96.89 & 1073. & 291.43 & 101 & \pm 204.25 \\
\hline \multicolumn{2}{|l|}{30} & 1148 & 113.33 & 989. & 16.17 & 106 & \pm 113.15 \\
\hline \multicolumn{2}{|l|}{60} & 1265 & 73.38 & 1040 & 20.00 & 115 & \pm 132.46 \\
\hline \multicolumn{2}{|l|}{90} & 1766 & 80.82 & 1433 & 41.63 & 160 & \pm 191.42 \\
\hline \multicolumn{2}{|c|}{ Average } & 1284 & 322.29 & 1134. & 222.35 & 120 & \pm 281.48 \\
\hline \multicolumn{8}{|c|}{ Average NPK levels } \\
\hline \multicolumn{2}{|c|}{0} & 1156 & 227.17 & 1176. & 217.77 & 116 & \pm 212.44 \\
\hline \multicolumn{2}{|l|}{30} & 1464 & 364.12 & 1188. & 218.37 & 132 & \pm 320.57 \\
\hline \multicolumn{2}{|l|}{60} & 1620 & 397.98 & 1491. & 495.27 & 155 & \pm 433.63 \\
\hline \multicolumn{2}{|l|}{90} & 2020 & 320.50 & 1753. & 352.06 & 188 & \pm 350.03 \\
\hline \multicolumn{2}{|c|}{ Average } & 1565 & 444.96 & 1402. & 400.55 & 148 & \pm 426.83 \\
\hline LSD & $\mathbf{Y}$ & RS & $\mathbf{V}$ & $\mathbf{R S} \times \mathbf{Y}$ & $\mathbf{R S} \times \mathbf{V}$ & $\mathbf{V} \times \mathbf{Y}$ & $\mathbf{R S} \times \mathbf{Y} \times \mathbf{V}$ \\
\hline \multirow{2}{*}{$\begin{array}{l}0.5 \\
0.1\end{array}$} & 68.022 & 68.022 & 96.209 & 96.209 & 136.061 & 136.061 & 192.418 \\
\hline & 91.488 & 91.488 & 129.398 & 129.398 & 182.998 & 129.998 & 258.798 \\
\hline
\end{tabular}

P-Parameter; GY—Grain yield; Y-Year; RS—Row spacing; V-Variant. 


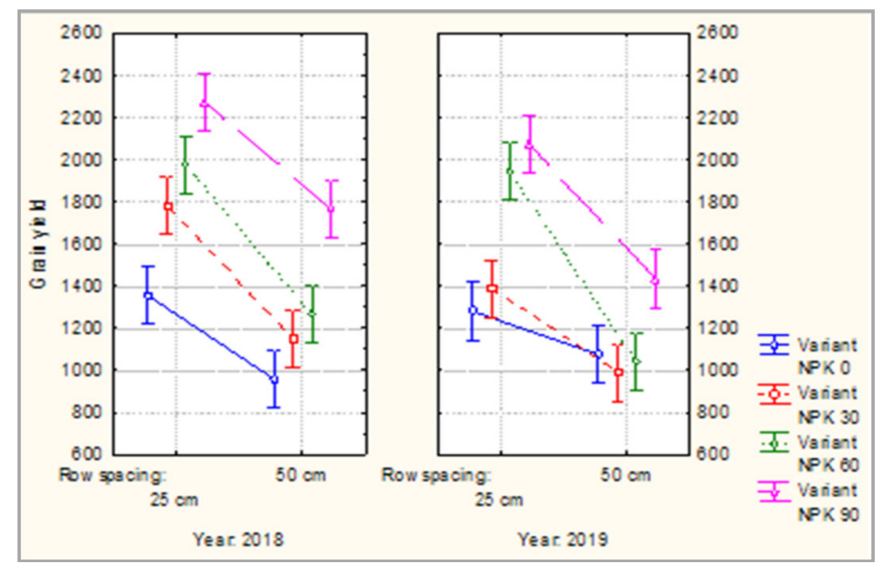

(a)

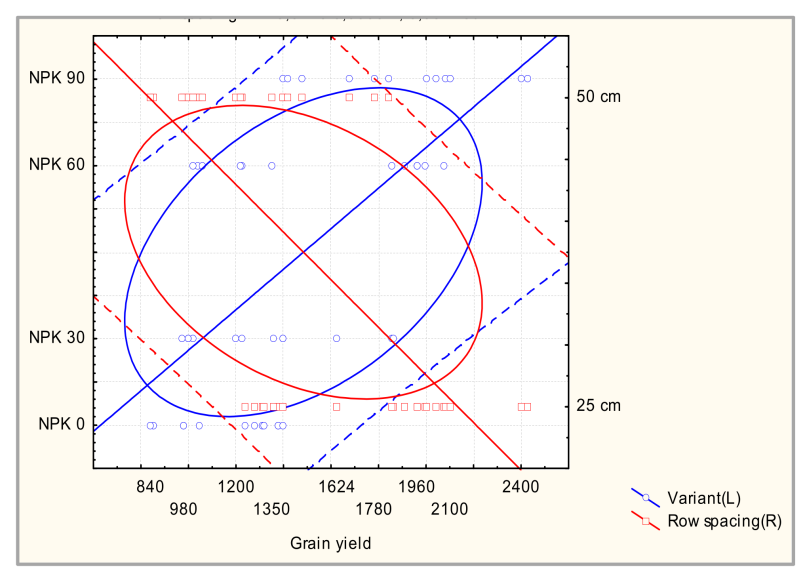

(b)

Figure 3. Effect of row spacing and NPK nutrition on GY (a), and interaction of year, row spacing, and NPK on yield (b).

The grain yield of buckwheat is influenced by year, row spacing, and variant nutrition (Table 2, Figure 3a,b). The seed yield was significantly influenced by all factors examined: row spacing, test year, and nutrition $(p<0.05$ and $p<0.01)$.

The interaction of the investigated factors, $\mathrm{V} \times \mathrm{Y}, \mathrm{Y} \times \mathrm{SD}$, and $\mathrm{SD} \times \mathrm{V}$ had a significant effect on the investigated parameters ( $p<0.05$, Figure 3a). In 2018, a significantly higher seed yield was achieved $\left(\mathrm{Y}_{1}=1565.5 \mathrm{~kg} \mathrm{ha}^{-1}\right)$ compared to $2019\left(\mathrm{Y}_{2}=1402.4 \mathrm{~kg} \mathrm{ha}^{-1}\right)$ $(p<0.05$, Table 2$)$.

At narrower row spacing, significantly higher seed yield was achieved $\left(\mathrm{RS}_{1}=\right.$ $\left.1758.7 \mathrm{~kg} \mathrm{ha}^{-1}\right)$ relative to the wider spacing $\left(\mathrm{RD}_{2}=1209.3 \mathrm{~kg} \mathrm{ha}^{-1}\right)$ (Table 2, Figure 3a,b).

The highest grain yield (2020.66 kg ha ${ }^{-1}$ ) was achieved in 2018 in nutrition variant with an application of $90 \mathrm{~kg}$ NPK; see Table 2.

A significantly lower average seed yield for the studied period was achieved in the control variant $\left(\mathrm{N}_{1}=1166.5 \mathrm{~kg} \mathrm{ha}^{-1}\right)$ compared to the nutrition variants. The average seed yield increased with nutrient growth $\left(\mathrm{N}_{2}=1326.2 \mathrm{~kg} \mathrm{ha}^{-1}, \mathrm{~N}_{3}=1556.2 \mathrm{~kg} \mathrm{ha}^{-1}\right.$, and $\left.\mathrm{N}_{4}=1887.0 \mathrm{~kg} \mathrm{ha}^{-1}\right)$. A significantly higher seed yield was obtained in nutrition variant $\mathrm{N}_{4}$ compared to variants $\mathrm{N}_{1}$ and $\mathrm{N}_{2}(p<0.01$, Tables 2 and 3$)$.

Table 3. ANOVA for the grain yield.

\begin{tabular}{cccccc}
\hline Parameter & \multicolumn{5}{c}{ Grain Yield } \\
\hline Effect & SS & Deg. of Freed. & MS & F-Value & $p$-Value \\
\hline Intercept & $105,702,352$ & 1 & $105,702,352$ & $7903.620^{* *}$ & 0.000000 \\
\hline Row spacing-RS & $3,622,304$ & 1 & $3,622,304$ & $270.848^{* *}$ & 0.000000 \\
\hline Year-Y & 319,154 & 1 & 319,154 & $23.864^{* *}$ & 0.000028 \\
\hline Nutrition variant-V & $3,520,016$ & 3 & $1,173,339$ & $87.733^{* *}$ & 0.000000 \\
\hline RS $\times$ Y & 1900 & 1 & 1900 & $0.142^{\text {ns }}$ & 0.708716 \\
\hline RS $\times$ V & 388,554 & 3 & 129,518 & $9.684^{* *}$ & 0.000107 \\
\hline Y $\times$ V & 175,491 & 3 & 58,497 & 0.010887 \\
\hline RS $\times$ Y $\times$ V & 107,620 & 3 & 35,873 & $2.682^{\text {ns }}$ & 0.063298 \\
\hline Error & 427,965 & 32 & 13,374 & &
\end{tabular}

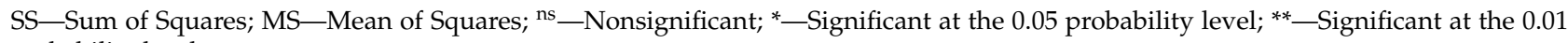
probability level.

Based on the analysis of variance, it can be concluded that there are highly significant differences in the grain yield between the tested years $\left(\mathrm{F}_{\exp }=23.864^{* *}\right)$, row spacing $\left(\mathrm{F}_{\exp }=270.848^{* *}\right)$, and nutrition $\left(\mathrm{F}_{\exp }=87.733^{* *}\right)$; see Table 3. The interaction of $\mathrm{RS} \times \mathrm{V}$ had a highly significant effect on grain yield $\left(\mathrm{F}_{\exp }=9.684^{* *}\right)$, while the $\mathrm{Y} \times \mathrm{V}$ interaction had a significant effect on grain yield $\left(\mathrm{F}_{\exp }=4.374{ }^{*}\right)$; see Table 3 . 


\subsubsection{Buckwheat Plant Height}

The plant height of buckwheat was affected by RS and V levels, as shown in Table 4. Plant height was significantly influenced by all factors examined and their interaction $(p<0.05$ and $p<0.01$; Table 4, Figure 4a,b).

Table 4. Effect of row spacing $(\mathrm{cm})$, year, and nutrition variant $\left(\mathrm{kg} \mathrm{ha}^{-1}\right)$ on plant height.

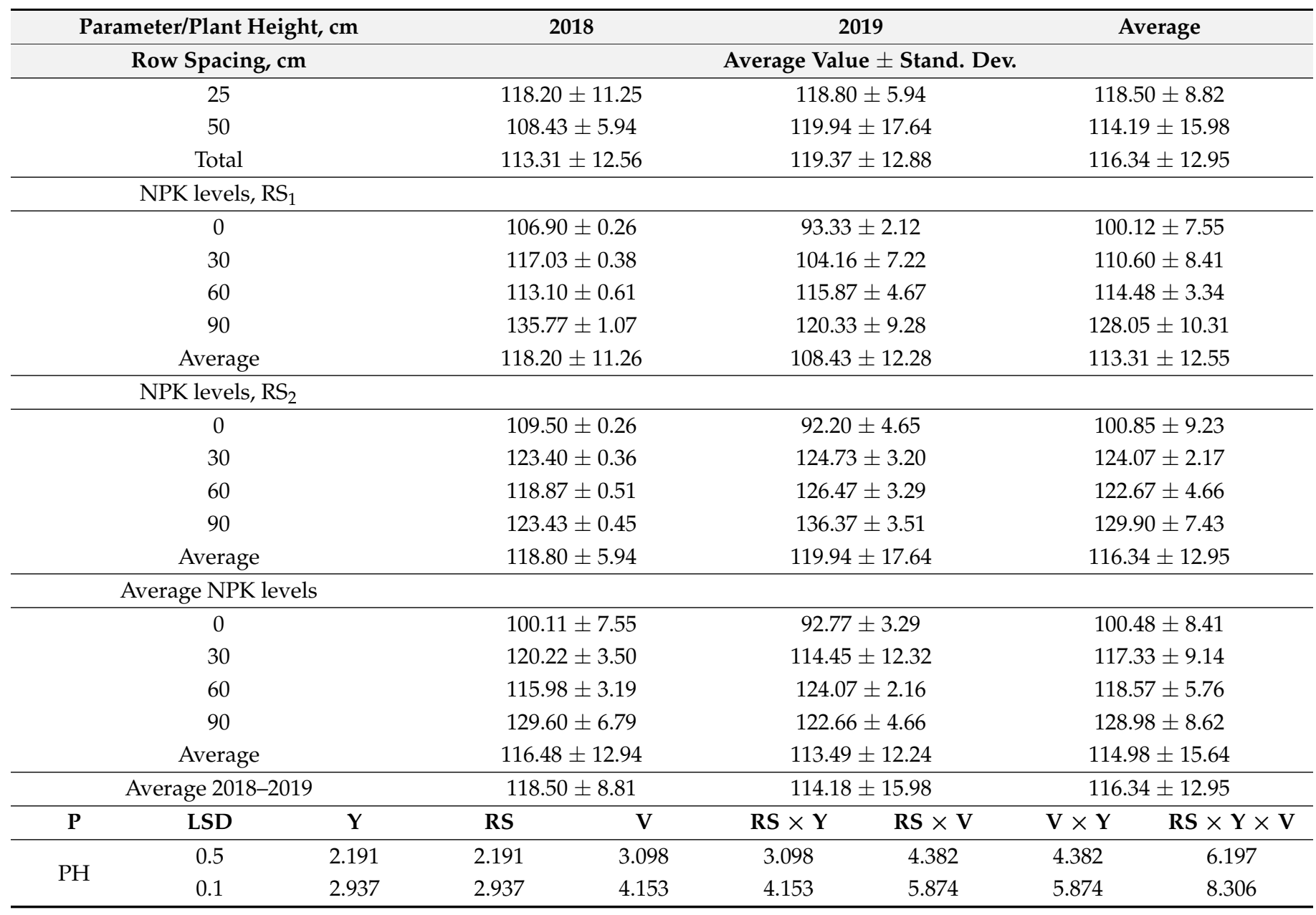

P—Parameter; PH—Plant height; Y—Year; RS—Row spacing; V—Variant.

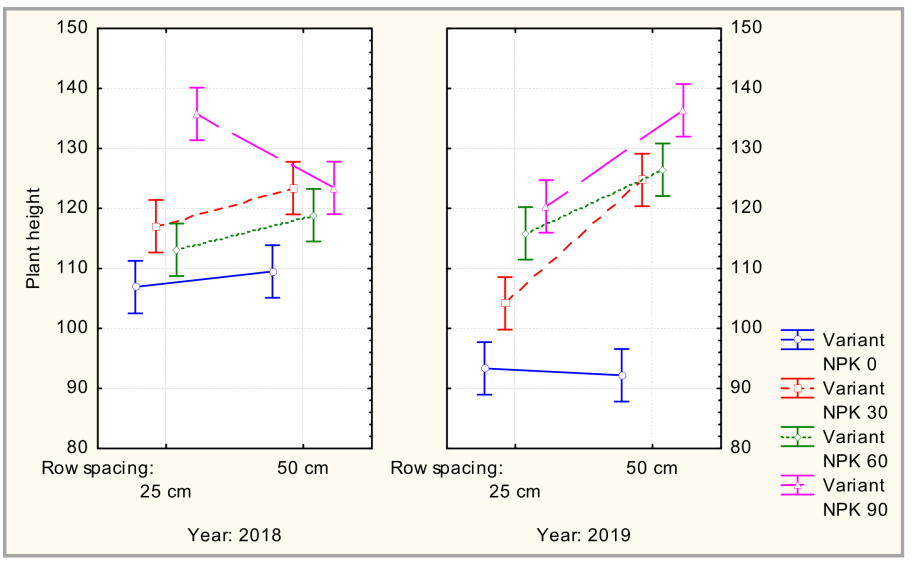

(a)

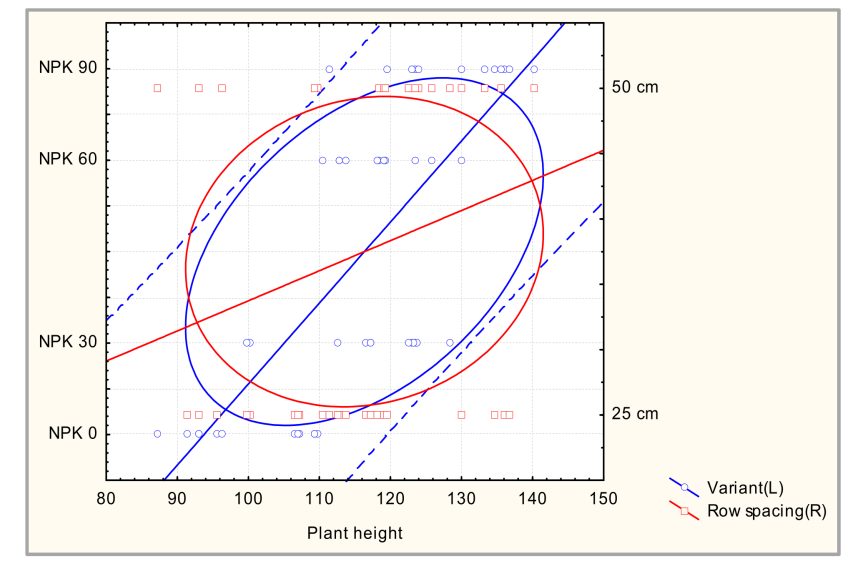

(b)

Figure 4. Effect of row spacing and NPK nutrition on PH (a), and interaction of year, row spacing, and NPK on plant height (b). 
Based on the analysis of variance, it can be concluded that there are highly significant differences in the plant height between tested years $\left(\mathrm{F}_{\exp }=16.12 * *\right)$, row spacing $\left(\mathrm{F}_{\text {exp }}=31.75^{* *}\right)$, and nutrition $\left(\mathrm{F}_{\mathrm{exp}}=120.27^{* *}\right)$; see Table 5 .

Table 5. ANOVA for the plant height.

\begin{tabular}{cccccc}
\hline Parameter & \multicolumn{5}{c}{ Plant Height } \\
\hline Effect & SS & Deg. of Freed. & MS & F-Value & $\boldsymbol{p}_{\text {-Value }}$ \\
\hline Intercept & $649,698.40$ & 1 & $649,698.58$ & $46,840.58^{* *}$ & 0.00000 \\
\hline Row spacing-RS & 440.40 & 1 & 440.45 & $31.75^{* *}$ & 0.00000 \\
\hline Year-Y & 223.60 & 1 & 223.60 & $16.12^{* *}$ & 0.00033 \\
\hline Nutrition variant-V & 5004.71 & 3 & 1668.20 & $20.27^{* *}$ & 0.00000 \\
\hline RS $\times$ Y & 357.51 & 1 & 357.50 & $7.60^{*}$ & 0.00001 \\
\hline RS $\times$ V & 316.40 & 3 & 105.50 & $16.25^{* *}$ & 0.00056 \\
\hline Y $\times$ V & 676.01 & 3 & 225.30 & $10.22^{* *}$ & 0.00000 \\
\hline RS $\times$ Y $\times$ V & 425.20 & 3 & 141.70 & 0.00007 \\
\hline Error & 443.91 & 32 & 13.90 &
\end{tabular}

SS-Sum of Squares; MS—Mean of Squares; * and **-Significant at the 0.05 and 0.01 probability level.

The interaction of $\mathrm{RS} \times \mathrm{Y}, \mathrm{Y} \times \mathrm{V}$, and $\mathrm{RS} \times \mathrm{Y} \times \mathrm{V}$ had a highly significant effect on plant height $\left(\mathrm{F}_{\exp }=25.78^{* *} ; \mathrm{F}_{\exp }=16.25^{* *} ; \mathrm{F}_{\exp }=10.22^{* *}\right)$, while the RS $\times \mathrm{V}$ interaction had a significant effect on plant height $\left(\mathrm{F}_{\exp }=7.60 *\right)$; see Table 5 .

Significantly lower average values for plant height, for the studied period, were achieved in the control variant $\left(\mathrm{N}_{1}=100.48 \mathrm{~cm}\right)$ compared to the variants with nutrition.

Average values for the height of buckwheat plants increased with the growth of nutrients (117.33, 118.58, and $128.97 \mathrm{~cm}$ for $\mathrm{N}_{2}, \mathrm{~N}_{3}$, and $\mathrm{N}_{4}$, respectively). Significantly higher values for plant height were obtained in variant $\mathrm{N}_{4}$ compared to variants $\mathrm{N}_{1}, \mathrm{~N}_{2}$, and $\mathrm{N}_{3}(p<0.01$, Table 4$)$.

According to Lalevic et al. [17], the conditions of the external environment, as well as the certain nutritional elements, significantly influenced the plant height and thousand grain weight.

\subsubsection{Number of Lateral Branches per Plant}

The effects of year, row spacing, and nutrition variant on the number of lateral branches per plant (NoLB) of buckwheat are shown in Tables 6 and 7 and Figure 5a.

The number of lateral branches per plant was significantly influenced by year, nutrition, and the interaction of RS $\times \mathrm{V}, \mathrm{Y} \times \mathrm{V}$, and the interaction of $\mathrm{RS} \times \mathrm{Y} \times \mathrm{V}(p<0.05$ and $p<0.01)$.

In 2018, significantly smaller NoLB values were achieved compared to $2019(p<0.05)$. Row spacing had a nonsignificant effect on NoLB. There were more lateral branches in the wider row spacing (Table 6, Figure 5b).

A significantly smaller average NoLB during the study period was achieved in the control variant $\left(\mathrm{N}_{1}=1.94\right)$ compared to other variants of nutrition. The average value of the NoLB increased with the increase in nutrients. A significantly higher value of NoLB was achieved in variant $\mathrm{N}_{4}$ compared to variant $\mathrm{N}_{1}(p<0.01$, Table 6, Figure 5a,b).

On the basis of the ANOVA, the years, nutrition, interaction of $\mathrm{RS} \times \mathrm{V}, \mathrm{Y} \times \mathrm{V}$, and interaction of $\mathrm{RS} \times \mathrm{Y} \times \mathrm{V}$ had a significant influence on the NoLB $(p<0.05$ and $p<0.01$; $\mathrm{F}_{\exp }=10.010^{* *} ; \mathrm{F}_{\exp }=33.420^{* *} ; \mathrm{F}_{\exp }=31.080^{* *}$, respectively). The row spacing had a nonsignificant effect on the number of lateral branches, $\mathrm{F}_{\exp }=0.050 *$ and $\mathrm{RS} \times \mathrm{V}$ interaction, $\mathrm{F}_{\exp }=0.851$; see Table 7. In 2018, there were significantly fewer lateral branches per plant compared to $2019(p<0.05)$. 
Table 6. Effect of row spacing $(\mathrm{cm})$ and nutrition $\left(\mathrm{kg} \mathrm{ha}^{-1}\right)$ of number of lateral branches per plant.

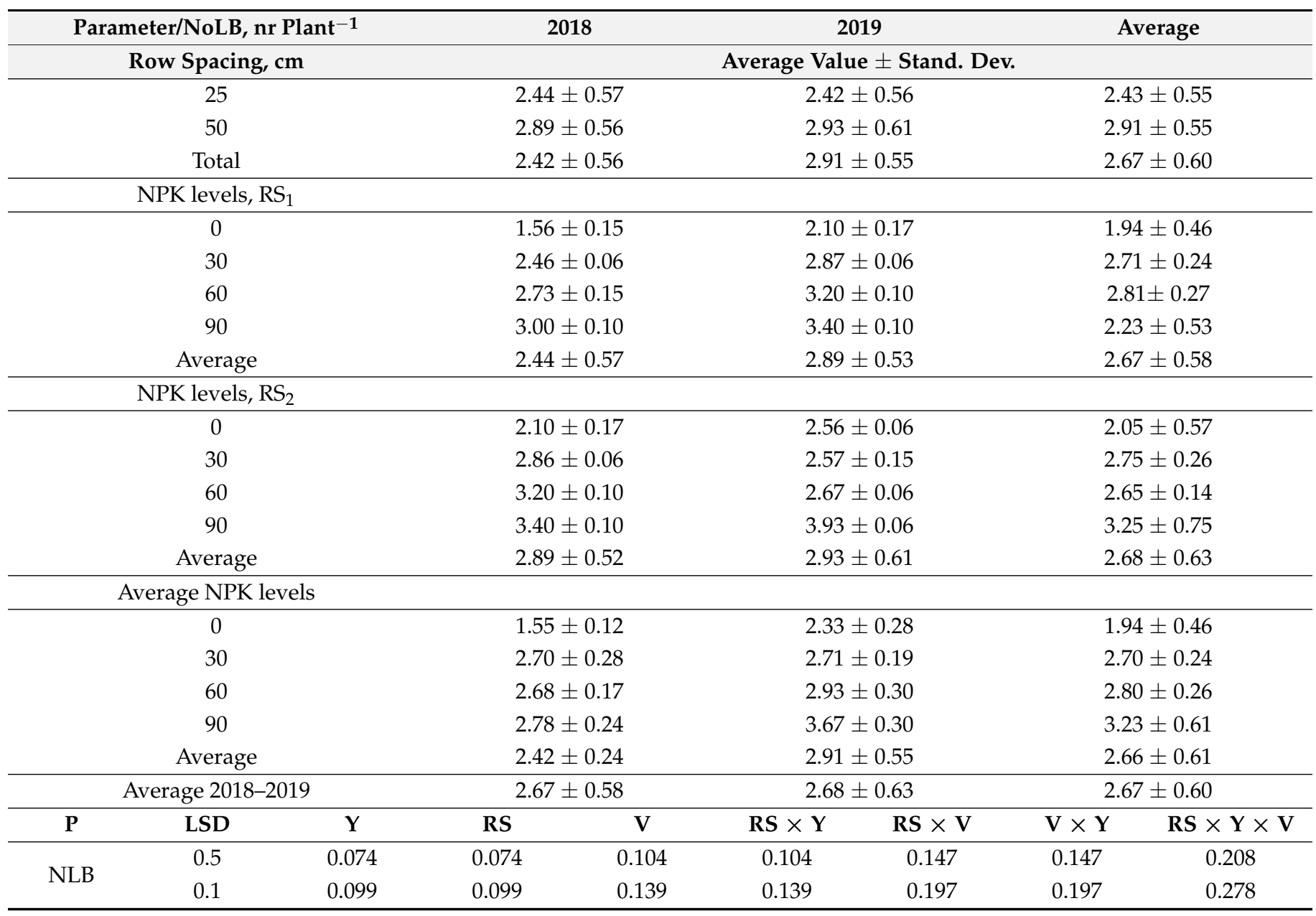

P—Parameter; NoLB — Number of lateral branches; Y—Year; RS—Row spacing; V—Variant.

Table 7. ANOVA for the number of lateral branches per plant.

\begin{tabular}{cccccc}
\hline Parameter & \multicolumn{5}{c}{ Number of Lateral Branches } \\
\hline Effect & SS & Deg. of Freed. & MS & $\boldsymbol{F}$ & $\boldsymbol{p}$ \\
\hline Intercept & 342.4008 & 1 & 342.4008 & $21,913.650^{* *}$ & 0.000000 \\
\hline Row spacing-RS & 0.0008 & 1 & 0.0008 & $0.050^{\text {ns }}$ & 0.818830 \\
\hline Year-Y & 2.8033 & 1 & 2.8033 & $179.410^{* *}$ & 0.000000 \\
\hline Nutrition variant-V & 10.3092 & 3 & 3.4364 & $219.930^{* *}$ & 0.000000 \\
\hline RS $\times$ Y & 0.0133 & 1 & 0.0133 & $0.851^{\text {ns }}$ & 0.362525 \\
\hline RS $\times$ V & 0.4692 & 3 & 0.1564 & $10.010^{* *}$ & 0.000083 \\
\hline Y $\times$ V & 1.5667 & 3 & 0.5222 & $33.420^{* *}$ & 0.000000 \\
\hline RS $\times$ Y $\times$ V & 1.4567 & 3 & 0.4856 & $31.080^{* *}$ & 0.000000 \\
\hline Error & 0.5000 & 32 & 0.0156 & &
\end{tabular}




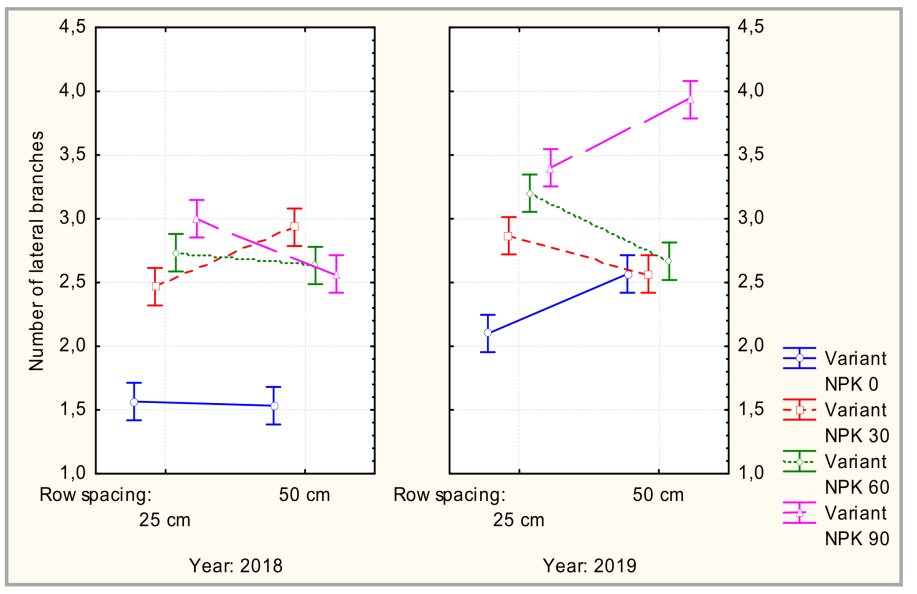

(a)

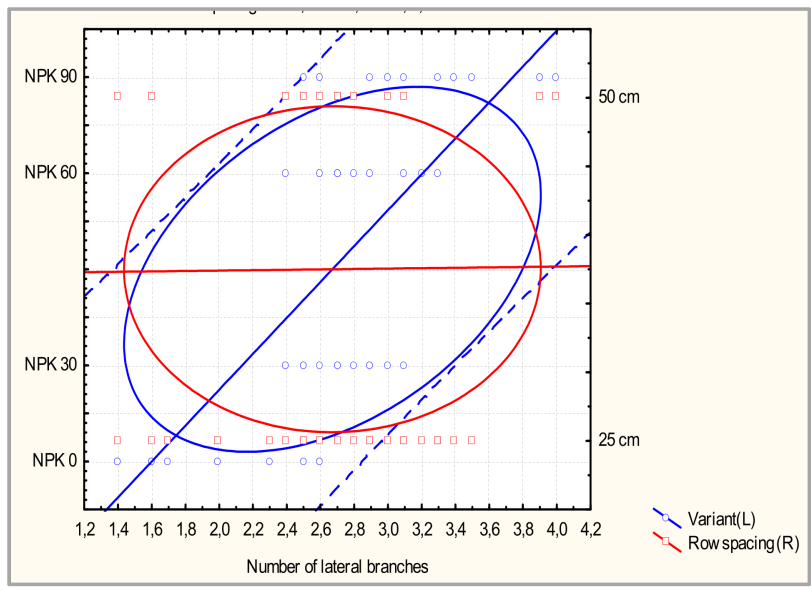

(b)

Figure 5. Effect of row spacing and NPK nutrition on NLB (a) and interaction of year, row spacing, and NPK on NLB (b).

\subsubsection{Mass of Seed per Plant}

In 2018, a significantly higher MSP $\left(\mathrm{Y}_{1}=0.94 \mathrm{~g}\right)$ was achieved compared to 2019 $\left(\mathrm{Y}_{2}=0.77 \mathrm{~g}\right)(p<0.05$; Table 8$)$. At narrow row spacing, a significantly higher MSP $\left(\mathrm{RS}_{1}=0.94 \mathrm{~g}\right)$ was achieved compared to wider row spacing $\left(\mathrm{RS}_{2}=0.76 \mathrm{~g}\right)$ (Table 8, Figure $6 \mathrm{a}, \mathrm{b})$.

Table 8. Effect of row spacing $(\mathrm{cm})$ and nutrition variant $\left(\mathrm{kg} \mathrm{ha}^{-1}\right)$ of mass of seed per plant (MSP).

\begin{tabular}{|c|c|c|c|c|c|c|}
\hline \multicolumn{3}{|c|}{ Parameter/Mass of Seed, g Plant $^{-1}$} & 2018 & 2019 & & rage \\
\hline \multicolumn{3}{|c|}{ Row Spacing, cm } & \multicolumn{4}{|c|}{ Average Value \pm Stand. Dev. } \\
\hline \multicolumn{3}{|c|}{25} & $1.00 \pm 0.37$ & $0.87 \pm 0.23$ & \multicolumn{2}{|c|}{$0.93 \pm 0.31$} \\
\hline \multicolumn{3}{|c|}{50} & $0.87 \pm 0.41$ & $0.66 \pm 0.18$ & \multicolumn{2}{|c|}{$0.77 \pm 0.33$} \\
\hline \multicolumn{3}{|c|}{ Total } & $0.94 \pm 0.30$ & $0.77 \pm 0.32$ & \multicolumn{2}{|c|}{$0.85 \pm 0.33$} \\
\hline \multicolumn{7}{|c|}{ NPK levels, $\mathrm{RS}_{1}$} \\
\hline \multicolumn{3}{|c|}{0} & $0.60 \pm 0.10$ & $0.57 \pm 0.06$ & \multicolumn{2}{|c|}{$0.58 \pm 0.14$} \\
\hline \multicolumn{3}{|c|}{30} & $0.80 \pm 0.10$ & $0.78 \pm 0.08$ & \multicolumn{2}{|c|}{$0.79 \pm 0.13$} \\
\hline \multicolumn{3}{|c|}{60} & $1.20 \pm 0.10$ & $1.03 \pm 0.08$ & \multicolumn{2}{|c|}{$1.12 \pm 0.16$} \\
\hline \multicolumn{3}{|c|}{90} & $1.40 \pm 0.11$ & $1.11 \pm 0.11$ & \multicolumn{2}{|c|}{$1.26 \pm 0.21$} \\
\hline \multicolumn{3}{|c|}{ Average } & $1.00 \pm 0.37$ & $0.87 \pm 0.42$ & \multicolumn{2}{|c|}{$0.94 \pm 0.39$} \\
\hline \multicolumn{7}{|c|}{ NPK levels, $\mathrm{RS}_{2}$} \\
\hline \multicolumn{3}{|c|}{0} & $0.60 \pm 0.20$ & $0.48 \pm 0.07$ & \multicolumn{2}{|c|}{$0.54 \pm 0.15$} \\
\hline \multicolumn{3}{|c|}{30} & $0.64 \pm 0.32$ & $0.64 \pm 0.15$ & & $=0.22$ \\
\hline & 60 & & $1.00 \pm 0.40$ & $0.67 \pm 0.14$ & & $=0.32$ \\
\hline & 90 & & $1.27 \pm 0.42$ & $0.85 \pm 0.12$ & & $=0.36$ \\
\hline & Average & & $0.88 \pm 0.41$ & $0.66 \pm 0.18$ & & $=0.33$ \\
\hline & ge NPK & & & & & \\
\hline & 0 & & $0.60 \pm 0.17$ & $0.52 \pm 0.08$ & & $=0.13$ \\
\hline & 30 & & $0.72 \pm 0.26$ & $0.71 \pm 0.13$ & & $=0.19$ \\
\hline & 60 & & $1.10 \pm 0.31$ & $0.85 \pm 0.22$ & & $=0.28$ \\
\hline & 90 & & $1.33 \pm 0.30$ & $0.98 \pm 0.18$ & & $=0.29$ \\
\hline & Average & & $0.93 \pm 0.30$ & $0.76 \pm 0.32$ & & $=0.32$ \\
\hline $\mathbf{P}$ & LSD & $\mathbf{Y}$ & RS & $\mathbf{R S} \times \mathbf{V}$ & $\mathbf{V} \times \mathbf{Y}$ & $\mathbf{R S} \times \mathbf{Y} \times \mathbf{V}$ \\
\hline MSP & 0.5 & 0.126 & 0.125 & 0.251 & 0.252 & 0.355 \\
\hline IVSP & 0.1 & 0.169 & 0.169 & 0.338 & 0.337 & 0.478 \\
\hline
\end{tabular}




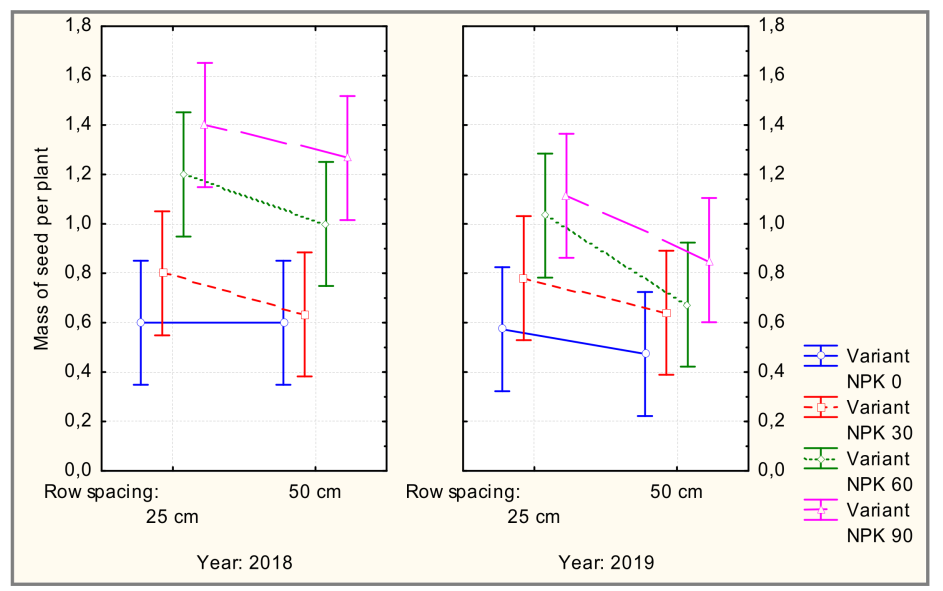

(a)

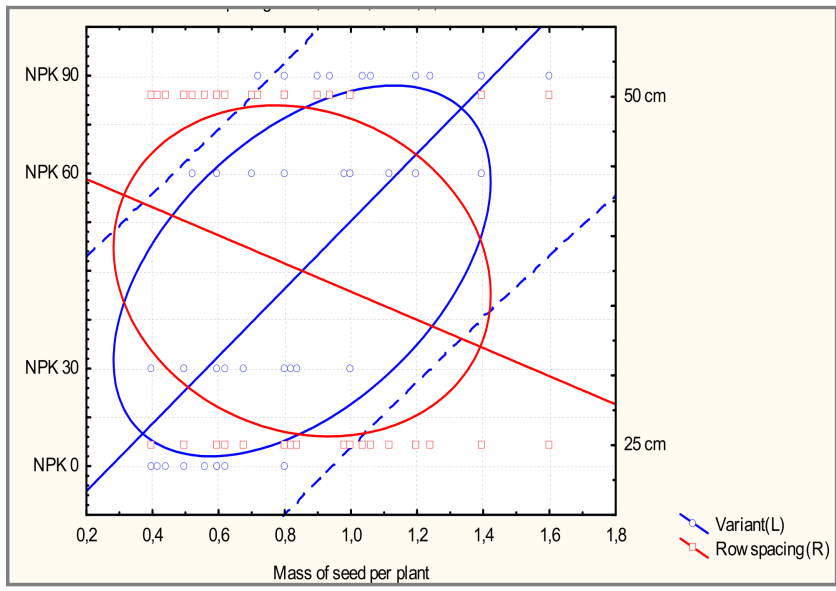

(b)

Figure 6. Effect of row spacing and NPK nutrition on MSP (a), and interaction of year, row spacing, and NPK on MSP (b).

A significantly lower average mass of seed per plant, in the study period, was achieved in the control variant $\left(\mathrm{N}_{1}=0.56 \mathrm{~g}\right)$ compared to other nutrition treatments. The average seed mass grew with the increase in variants. Significantly higher MSP was in variant $\mathrm{N}_{4}$ compared to variants $\mathrm{N}_{1}$ and $\mathrm{N}_{2}(p<0.01$; Table 8$)$.

The mass of seed per plant (MSP) was significantly influenced by all factors examined $(p<0.01$; Table 9, Figure 6a,b). On the basis of the ANOVA, the row spacing, years, and nutrition had a highly significant influence on the MSP $\left(p<0.01 ; \mathrm{F}_{\exp }=7.6150\right.$ **; $\mathrm{F}_{\exp }=7.6151^{* *} ; \mathrm{F}_{\exp }=18.6996^{* *}$, respectively). They had a nonsignificant effect on the interaction of the tested factor; see Table 9.

Table 9. ANOVA table for the mass of seed per plant.

\begin{tabular}{cccccc}
\hline Parameter & \multicolumn{5}{c}{ Mass of Seed per Plant } \\
\hline Effect & SS & Deg. of Freed. & MS & F-Value & $p$-Value \\
\hline Intercept & 34.88430 & 1 & 34.88430 & $765.9865^{* *}$ & 0.00000 \\
\hline Row spacing-RS & 0.34680 & 1 & 0.34680 & $7.6150^{* *}$ & 0.00949 \\
\hline Year-Y & 0.34680 & 1 & 0.34680 & $7.6150^{* *}$ & 0.00949 \\
\hline Nutrition variant-V & 2.55483 & 3 & 0.85160 & $18.6996^{* *}$ & 0.00000 \\
\hline RS $\times$ Y & 0.02430 & 1 & 0.02430 & $0.5336^{\text {ns }}$ & 0.47042 \\
\hline RS $\times$ V & 0.08247 & 3 & 0.02749 & $0.6036^{\text {ns }}$ & 0.61745 \\
\hline Y $\times$ V & 0.22100 & 3 & 0.07367 & $1.6176^{\text {ns }}$ & 0.20465 \\
\hline RS $\times$ Y $\times$ V & 0.01497 & 3 & 0.00499 & $0.1096^{\text {ns }}$ & 0.95390 \\
\hline Error & 1.45733 & 32 & 0.04554 & &
\end{tabular}

SS-Sum of Squares; MS—Mean of Squares; ${ }^{\text {ns }}$-Nonsignificant; ${ }^{* *}$-Significant at the 0.01 probability level.

In addition, our research findings align with those of Popovic et al. [19]; they state that the inter-row spacing and nutrition had significant effects on MSP. Significantly lower MSP and seed yield were achieved at a $50 \mathrm{~cm}$ row spacing and in the control variant compared to the variants where nutrition was added. Depending on the row spacing, MSP varied from $0.45 \mathrm{~g}(50 \mathrm{~cm})$ to $0.50 \mathrm{~g}(25 \mathrm{~cm})$, while seed yield varied from $700 \mathrm{~kg} \mathrm{ha}^{-1}(50 \mathrm{~cm})$ to $980 \mathrm{~kg} \mathrm{ha}^{-1}(25 \mathrm{~cm})$. Significantly lower yields were achieved in the control variant compared to the variant with added nutrition.

\subsubsection{Number of Seeds per Plant}

The number of seeds per plant (NoSP) was significantly affected by all factors examined $(p<0.01$; Figure 7a,b). In 2018, a significantly higher NoSP was achieved compared 
to 2019 (Table 10). In narrower row spacing, a significantly higher NoSP was achieved compared to wider spacing (Tables 10 and 11).

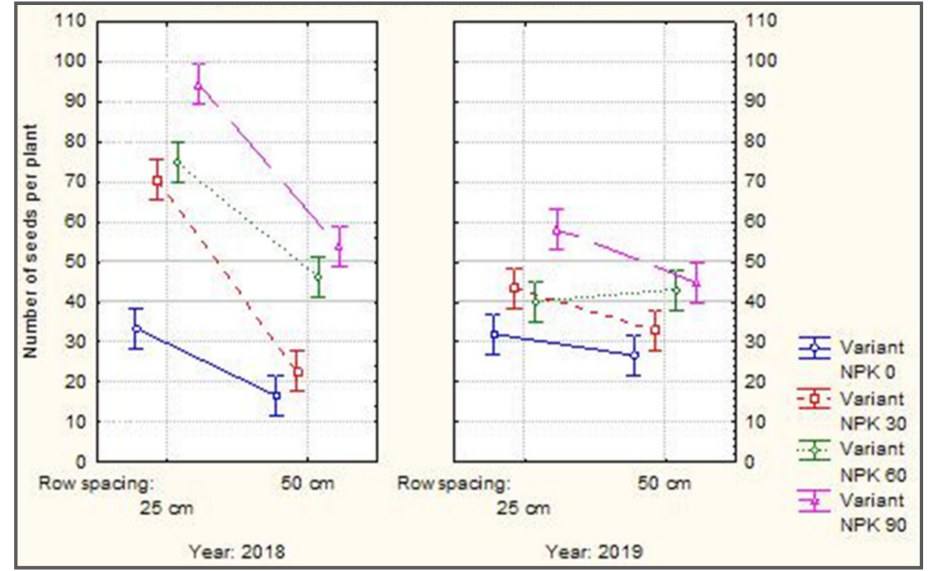

(a)

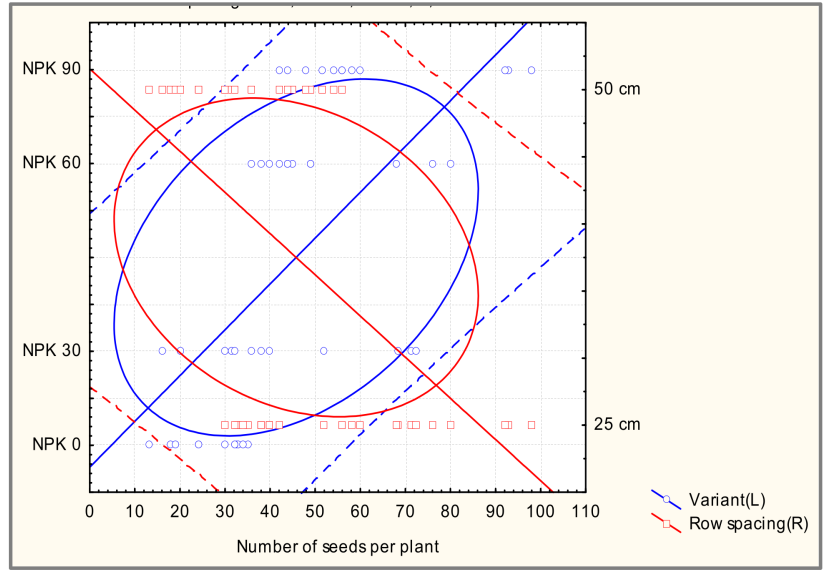

(b)

Figure 7. Effect of row spacing and NPK nutrition on NoSP (a), and interaction of year, row spacing, and NPK on NoSP (b).

Table 10. Effect of row spacing $(\mathrm{cm})$ and nutrition variant $\left(\mathrm{kg} \mathrm{ha}^{-1}\right)$ on the number of seeds per plant.

\begin{tabular}{|c|c|c|c|}
\hline \multirow{2}{*}{$\begin{array}{c}\text { Parameter/Number of Seed, } \mathrm{nr}^{\text {Plant }^{-1}} \\
\text { Row Spacing, } \mathrm{cm}\end{array}$} & 2018 & 2019 & Average \\
\hline & & \multicolumn{2}{|c|}{ Average Value \pm Stand. Dev. } \\
\hline 25 & $68.27 \pm 23.18$ & $43.33 \pm 10.33$ & $55.80 \pm 21.72$ \\
\hline 50 & $34.77 \pm 16.72$ & $36.75 \pm 8.66$ & $35.76 \pm 13.06$ \\
\hline Total & $51.52 \pm 26.14$ & $40.04 \pm 9.98$ & $45.78 \pm 20.41$ \\
\hline \multicolumn{4}{|l|}{ NPK levels, $\mathrm{RS}_{1}$} \\
\hline 0 & $33.47 \pm 1.33$ & $32.00 \pm 2.00$ & $25.04 \pm 9.49$ \\
\hline 30 & $70.67 \pm 2.05$ & $43.33 \pm 7.57$ & $46.64 \pm 26.83$ \\
\hline 60 & $74.66 \pm 6.11$ & $40.00 \pm 2.00$ & $60.33 \pm 16.26$ \\
\hline 90 & $94.27 \pm 3.25$ & $58.00 \pm 2.00$ & $74.07 \pm 22.27$ \\
\hline Average & $68.27 \pm 23.18$ & $43.33 \pm 10.46$ & $51.52 \pm 26.14$ \\
\hline \multicolumn{4}{|l|}{ NPK levels, $\mathrm{RS}_{2}$} \\
\hline 0 & $16.60 \pm 3.17$ & $26.66 \pm 4.61$ & $21.63 \pm 6.55$ \\
\hline 30 & $22.60 \pm 7.87$ & $32.66 \pm 3.05$ & $27.63 \pm 7.67$ \\
\hline 60 & $46.00 \pm 2.65$ & $43.00 \pm 6.55$ & $44.50 \pm 4.76$ \\
\hline 90 & $53.87 \pm 2.21$ & $43.03 \pm 6.56$ & $49.27 \pm 5.57$ \\
\hline Average & $34.76 \pm 16.72$ & $36.75 \pm 8.67$ & $35.76 \pm 13.07$ \\
\hline \multicolumn{4}{|l|}{ Average NPK levels } \\
\hline 0 & $25.03 \pm 9.49$ & $29.33 \pm 4.32$ & $27.18 \pm 7.38$ \\
\hline 30 & $46.63 \pm 26.83$ & $38.00 \pm 7.79$ & $42.32 \pm 19.37$ \\
\hline 60 & $60.33 \pm 16.25$ & $41.50 \pm 4.64$ & $50.92 \pm 15.05$ \\
\hline 90 & $74.07 \pm 22.27$ & $51.33 \pm 7.66$ & $62.70 \pm 19.82$ \\
\hline Average & $51.51 \pm 26.14$ & $40.04 \pm 9.97$ & $45.77 \pm 20.41$ \\
\hline LSD & RS $\quad$ V & $R S \times Y \quad R S \times V$ & $\mathbf{V} \times \mathbf{Y} \quad \mathbf{R S} \times \mathbf{Y} \times \mathbf{V}$ \\
\hline 2.506 & 3.544 & 3.544 & 7.087 \\
\hline 3.370 & 3.371 & 4.765 & 9.532 \\
\hline
\end{tabular}

P-Parameter; NoSP-Number of seeds per plant; Y-Year; RS—Row spacing; V—Variant. 
Table 11. ANOVA table for the number of seeds per plant.

\begin{tabular}{cccccc}
\hline Parameter & \multicolumn{5}{c}{ Number of Seeds per Plant } \\
\hline Effect & SS & Deg. of Freed. & MS & F-Value & $p$-Value \\
\hline Intercept & $100,595.20$ & 1 & $100,595.00$ & $5544.72^{* *}$ & 0.00000 \\
Row spacing-RS & 4820.00 & 1 & 4820.00 & $265.676^{* *}$ & 0.00000 \\
Year-Y & 1580.10 & 1 & 1580.10 & $87.094^{* *}$ & 0.00000 \\
Nutrition variant-V & 8046.00 & 3 & 2682.05 & $147.830^{* *}$ & 0.00000 \\
RS $\times$ Y & 2173.50 & 1 & 2173.50 & $119.803^{* *}$ & 0.00000 \\
RS $\times$ V & 796.30 & 3 & 265.40 & $14.631^{* *}$ & 0.00000 \\
Y $\times$ V & 1313.50 & 3 & 437.80 & $24.132^{* *}$ & 0.00000 \\
RS $\times$ Y $\times$ V & 276.80 & 3 & 92.30 & $5.087^{*}$ & 0.005420 \\
Error & 580.00 & 32 & 18.10 & & \\
\hline
\end{tabular}

SS-Sum of Squares; MS—Mean of Squares; * and ** —Significant at the 0.05 and 0.01 probability level.

A significantly lower NoSP was obtained in the control variant $\left(\mathrm{N}_{1}=27\right)$ compared to the $\mathrm{N}_{2}-\mathrm{N}_{4}$ variants. The number of seeds increased with the increase in nutrients. A significantly higher number of seeds was obtained in variant $\mathrm{N}_{4}$ compared to variant $\mathrm{N}_{1}$ and $\mathrm{N}_{2}(p<0.01$; Tables 10 and 11).

On the basis of the ANOVA, the row spacing, years, and nutrition had a highly significant influence on the NoSP $\left(p<0.01 ; F_{\exp }=265.676^{* *} ; F_{\exp }=87.094^{* *} ; F_{\exp }=147.830^{* *}\right.$; respectively). There was a highly significant effect on the interaction of the tested factors; see Table 11.

Increasing density decreased the grains number per plant, while DM weight and yield displayed an acceleration first and then deceleration. The results of Xiang et al. (2016) suggested that planting density could alter the traits, resistance, and yield of buckwheat.

The findings of our research are also in line with those of Popovic et al. [19]. These authors stated that based on the ANOVA, row spacing and nutrition had a significant effect on the NoSP. A significantly lower NoSP was achieved at $50 \mathrm{~cm}$ row spacing and in the control variant compared to the variants with added nutrition. Depending on the row spacing, NoSP varied from $23(50 \mathrm{~cm})$ to $34(25 \mathrm{~cm})$.

\subsubsection{Correlations between the Analyzed Traits}

Grain yield was positive and highly correlated with NoSP, MSP, and variant and there was a positive significant correlation with plant height (PH), NoLB, and nonsignificant positive correlation with temperature (Table 12).

Table 12. Correlation of tested parameters of buckwheat, 2018-2019.

\begin{tabular}{ccccccccccc}
\hline Parameter & PH & NoLB & NoSP & MSP & GY & V & RS & T & P \\
\hline PH & 1.00 & $0.54^{*}$ & $0.43^{*}$ & $0.44^{*}$ & $0.30^{*}$ & $0.72^{*}$ & $0.24^{\mathrm{ns}}$ & $0.17^{\mathrm{ns}}$ & $-0.10^{\mathrm{ns}}$ \\
NoLB & $0.54^{*}$ & 1.00 & $0.35^{*}$ & $0.33^{*}$ & $0.41^{*}$ & $0.71^{*}$ & $0.01^{\mathrm{ns}}$ & $-0.40^{*}$ & $0.43^{*}$ \\
NoSP & $0.43^{*}$ & $0.35^{*}$ & 1.00 & $0.69^{*}$ & $0.81^{*}$ & $0.62^{*}$ & $-0.50^{*}$ & $0.28^{\mathrm{ns}}$ & $-0.26^{\mathrm{ns}}$ \\
MSP & $0.44^{*}$ & $0.33^{*}$ & $0.69^{*}$ & 1.00 & $0.71^{*}$ & $0.71^{*}$ & $-0.26^{\mathrm{ns}}$ & $0.26^{\mathrm{ns}}$ & $-0.23^{\mathrm{ns}}$ \\
GY & $0.30^{*}$ & $0.41^{*}$ & $0.81^{* *}$ & $0.71^{*}$ & 1.00 & $0.63^{*}$ & $-0.65^{*}$ & $0.19^{\mathrm{ns}}$ & $-0.17^{\mathrm{ns}}$ \\
\hline
\end{tabular}

P-Parameter; PH—Plant height; NoLB—Number of lateral branches; NoSP—Number of seeds per plant; MSP—Mass of seeds per plant;

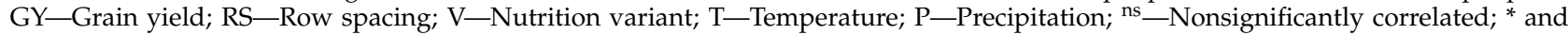
**-Significantly correlated at 0.01 and 0.05 .

The results indicated that the grain yield in all vegetation seasons was positive and highly correlated with $\operatorname{NoSP}\left(\mathrm{r}=0.81^{* *}\right)$, MSP $\left(\mathrm{r}=0.71^{*}\right)$, and variant $\left(\mathrm{r}=0.63^{*}\right)$. The grain yield was positively and significantly correlated with plant height $\left(r=0.30^{*}\right)$ and NoLB $\left(\mathrm{r}=0.41^{*}\right)$. Grain yield was nonsignificantly positive correlated with temperature $(\mathrm{r}=0.19)$ and nonsignificantly negatively correlated with precipitation $(r=0.17)$ (Table 12). 
Plant height in both seasons was positively and significantly correlated with nutrition variant $\left(r=0.72^{* *}\right), \operatorname{NoLB}\left(r=0.54^{*}\right), \operatorname{NoSP}\left(r=0.43^{* *}\right), \operatorname{MSP}\left(r=0.44^{*}\right)$, and grain yield $(\mathrm{r}=0.30 *)$. Plant height was nonsignificantly positively correlated with temperature $(r=0.17)$ and nonsignificantly negatively correlated with precipitation $(r=0.10)$ (Table 12)

The mass of seeds per plant in both seasons was positively and significantly correlated with GY $\left(r=0.71^{* *}\right)$, nutrition variant $\left(r=0.71^{* *}\right)$, NoSP $(r=0.69 *), P H\left(r=0.44^{*}\right)$, NoLB $\left(\mathrm{r}=0.33^{*}\right)$, and nonsignificantly positively correlated with temperature $(\mathrm{r}=0.26)$ and nonsignificantly negatively correlated with precipitation $(r=0.23)$ (Table 12).

The number of seeds per plant in both seasons was positively and high significantly correlated with GY $\left(\mathrm{r}=0.81^{* *}\right)$, nutrition variant $\left(\mathrm{r}=0.62^{*}\right)$, MSP $\left(\mathrm{r}=0.69^{*}\right), \mathrm{PH}\left(\mathrm{r}=0.43^{*}\right)$, and $\operatorname{NoLB}\left(\mathrm{r}=0.35^{*}\right)$, and nonsignificantly positively correlated with temperature $(\mathrm{r}=0.28)$. The number of seeds per plant was nonsignificantly negatively correlated with precipitation $(\mathrm{r}=0.26)$ (Table 12).

The number of lateral branches in all seasons was positively and significantly correlated with the nutrition variant $\left(\mathrm{r}=0.71^{*}\right), \mathrm{PH}\left(\mathrm{r}=0.54^{*}\right)$, $\operatorname{NoSP}\left(\mathrm{r}=0.35^{*}\right)$, GY $\left(\mathrm{r}=0.41^{* *}\right)$, $\operatorname{MSP}\left(r=0.33^{*}\right)$, precipitation $\left(r=0.43^{*}\right)$, and significantly negatively correlated with temperature $\left(\mathrm{r}=0.43^{*}\right)$ (Table 12$)$.

\section{Discussion}

The environment can have a crucial influence on plants' production in particular regions, even more so when production environments are different from optimum breeding environments [23,26,32,34]. The agro-meteorological conditions in 2010 were unfavorable for buckwheat production, which was primarily due to the poor distribution of precipitation and large temperature fluctuations during fertilization, which led to lower yields for the area [35].

Variations in the temperature and in the amount of precipitation during vegetation of buckwheat as well as in the moisture content in the soil are the most important factors of the instability of the yield [3,20,36]. Martinez et al. [37] emphasize that in the favorable productive years, yield was the highest in the conventional tillage compared with the no-tillage system. Maksimovic et al. [32] state that beside the choice of cultivar and proper agro-technical practices, buckwheat production is considerably affected by soil and climatic conditions. In dry conditions, the lack of water affects the nutrient supply of plants. The transport of nutrients to actively growing branches and flower buds is reduced, which in turn lowers grain yield and quality.

One of the plant's basic elements is $\mathrm{N}$. Buckwheat response to $\mathrm{N}$ depends on the total $\mathrm{N}$ content of the soil, climatic conditions, and $\mathrm{N}$ additives as well as its addition timing [34].

The supplementary nutrition of buckwheat plants increases grain yield [2,19], and the system of applied production technology (time and method of sowing) can increase the production productivity [5]. Nitrogen nutrition is an important yield-creating factor for buckwheat because it increases grain yield as well as the protein content in grains [38].

The increase in $\mathrm{N}$ can enhance biomass, leaf area, number of branches, and quantitative and qualitative grain yields. The influence of row spacing, plant density, and N nutrition on the number of branches and protein content increase has been observed [15,39].

At a row spacing of $50 \mathrm{~cm}$, buckwheat encountered competition with weeds Ambrosia artemisifolia and Cirsium sp., which resulted in a significantly lower grains yield; see Table 1. Similar results were obtained by Nozinic [21]. The optimal number of plants provides greater tolerance to adverse weather conditions [21].

Nozinic [21] points out that in a trial with three row spacings $(12.5,25$, and $50 \mathrm{~cm})$, planting density was in complete correlation with yield. The highest buckwheat grain yield of $2.43 \mathrm{t} \mathrm{ha}^{-1}$ was for $25 \mathrm{~cm}$ row spacing, while the yields were 1.54 and $1.53 \mathrm{t} \mathrm{ha}^{-1}$ respectively for $15 \mathrm{~cm}$ and $50 \mathrm{~cm}$. A planting rate of $12.5 \mathrm{~cm}$ caused crop lodging, and a rate of $50 \mathrm{~cm}$ caused more intensive development of weeds than of buckwheat.

Our data indicated significant positive correlations between plant height and total seed weight. Arshad et al. [40] reported significant positive correlations of grain yield 
with plant height. In gramineous crop plants, a taller stature is usually associated with higher yield.

The pattern of planting influenced the percentage of fat, seed yield, and the number of leaves in the plant. The sowing date influenced the percentage of protein, fat, and starch in the seed, the seed yield, the number of leaves in the plant, the thickness of the stem, and the height of the plant; the amount of nitrogen affected the percentage of protein and starch, seed yield, and the number of the leaves. Concerning the dual mutual effects, the pattern of planting and nitrogen influenced the percentage of protein, starch, and seed yield. The sowing date and nitrogen together influenced the percentage of protein, fat, starch, and seed yield. The pattern of planting and the sowing date influenced the percentage of protein, seed yield, and the number of the leaves. Regarding the triple mutual effects of sowing date $\times$ the pattern of planting $\times$ nitrogen, these three factors greatly influenced the amount of fat, starch, and protein, seed yield, and the number of leaves [41]. Özyazici [42] states that $\mathrm{N}$ doses had significant effects on seed yield, while some of the agricultural properties affected the yield and protein ratio. According to $\mathrm{N}$ doses, the plant height, branch number, number of leaves, number of inflorescence, biological yield, seed yield, thousand seed weight, and protein ratio were ranged within $63.00-71.50 \mathrm{~cm}, 3.28-5.00$ number plant ${ }^{-1}, 19.25-31.00$ number plant ${ }^{-1}, 12.75-23.50$ number plant $^{-1}, 3611.0-9936.0 \mathrm{~kg} \mathrm{ha}^{-1}, 588.0-1492.0 \mathrm{~kg} \mathrm{ha}^{-1}$, 19.39-23.52 g, and 10.72-13.65\%, respectively. It was concluded that $114.8 \mathrm{~kg} \mathrm{ha}^{-1}$ nitrogen can be applied in terms of seed yield in buckwheat cultivation in soils with low organic matter content.

Yokozawa et al. [43] reported that buckwheat polyphenol extract has a beneficial effect on patients with renal problems. The effect was probably due to the content of rutin, quercetin, hyperosid, and phenolic oligomers of buckwheat. The diversity of the antioxidative effect was connected to the interaction of genetic and environmental factors in buckwheat [44]. Rutin prevents capillary fragility and high blood pressure [44,45]. As reported by authors [46], more rutin is synthesized at higher temperature $\left(24.5^{\circ} \mathrm{C}\right.$ daytime and $18{ }^{\circ} \mathrm{C}$ at night) in comparison to lower temperature $\left(18^{\circ} \mathrm{C}\right.$ daytime and $12{ }^{\circ} \mathrm{C}$ at night $)$. The highest amounts of rutin were contained in the upper epidermis, and glycosidase was the most active in the lower epidermis. Wagenbreth et al. [47] found a variable rutin content ( $2 \%$ to $9 \%$, d.m.b. dry matter basis) in the leaves of different buckwheat cultivars. In leaves situated higher on the plant, there was more rutin than in the lower ones. They found the highest rutin content in the inflorescences (up to $12 \%$, d.m.b.).

Buckwheat is a nutritionally valuable crop that is an alternative to common cereals andalso usable in gluten-free diets. The selection of buckwheat genotypes suitable for further breeding requires the characterization and evaluation of genetic resources [48]. Significant differences among years and genotypes were observed for morphological traits $[49,50]$. Due to the great nutritional value of buckwheat, certification should be worked on as well as branding buckwheat products, because buckwheat has a significant place in programs of integral and organic production systems.

Crop management can significantly influence buckwheat yield, rutin, starch, and protein content [51]. The nutritive value of buckwheat seeds is much higher than that of cereal crops. Buckwheat is a green functional food. The buckwheat proteins are particularly rich in lysine and contain less glumatic acid and proline than cereal proteins as well as more arginine and aspartic acid. Buckwheat proteins also show a strong supplemental effect with other proteins to improve the dietary amino acid balance with special biological activities of cholesterol-lowering effects, antihypertension effects, and improving the constipation and obesity conditions by acting in a similar way as dietary fiber and interrupting the in vivo metabolisms. In addition to its high-quality proteins, buckwheat is also rich with flavones, flavonoids, phytosterols, D-chiro-inositol, and myo-inositol [50]. The protein content in buckwheat is approximately $12 \%$, the fat content is about $3 \%$, the crude fiber concentration is $15.8 \%$, the carbohydrates content is $48.7 \%$, and the tannin content is $1.76 \%$. The protein quality is very high, with a biological values above $90 \%$. Buckwheat is rich in polyphenols, including six flavonoids: rutin, orientin, vitexin, quercetin, isovitexin, and 
isoorientin. Among these antioxidant components, rutin was recognized as the most health protective and has also been proven to be anti-inflammatory and anticarcinogenic [5,52].

\section{Conclusions}

The method proposed by the present study for the evaluation of the effect of nutrition on buckwheat and row spacing was practical and efficient. Buckwheat grain yield was strongly dependent on row spacing, NPK nutrition, and weather conditions during the study years. Seed yield was significantly influenced by row spacing (RS), year (Y), and nutrition variant $(\mathrm{V})$, as well as the interaction of tested factors, $\mathrm{V} \times \mathrm{Y}, \mathrm{Y} \times \mathrm{RS}$, and RS $\times$ V. In 2018, there was a significantly higher seed yield. At a narrower row spacing, a significantly higher seed yield was achieved. Buckwheat grain yield was significantly positively correlated with the number of seeds per plant, mass of seeds per plant, and nutrition variant; and it was significantly positively correlated with plant height and the number of lateral branches and nonsignificantly positively correlated with temperature. The maximum grain productivity in a field experiment with buckwheat 'Novosadska' can be obtained at $90 \mathrm{~kg} \mathrm{ha}^{-1} \mathrm{NPK}$. The wide-narrow row spacing and nutrition are recognized as good management practices in crop production. Optimizing row spacing and nutrition for maximum profitability is of great importance in the future buckwheat production in Pannonian environments.

Author Contributions: Conceptualization, V.P. and D.S.; methodology, L.K.; software, V.P. and P.S.; validation, V.P., J.I. and L.Š.T.; formal analysis, V.P. and L.K.; investigation, V.P., L.K. and L.Ž.; resources, V.P.; data curation, L.K.; writing-original draft preparation, L.Š.T., J.I., V.P. and N.L.; writing - review and editing, N.L., P.S. and D.S.; visualization, J.I.; supervision, D.S.; project administration, V.P., D.S. and J.I. All authors have read and agreed to the published version of the manuscript.

Funding: This research received no external funding.

Acknowledgments: This paper is a part of the projects, Grant numbers: 451-03-9/2021-14/200032, 200045, 200116, and 200354, financed by the Ministry of Education, Science, and Technology Development of Republic of Serbia and Project Ideja (2021-2024): Optimization of agriculture and forestry biomass yield and quality for sustainable energy conversion; and Bilateral Project Republic of Serbia and Montenegro 2019-2022: Alternative cereals and oil crops as a source of healthcare food and an important raw material for the production of biofuel; and APV -Autonomous Province of Vojvodina Project, Provincial Secretariat for higher education and scientific research, 2021-2024: Alternative cereals and oil flax as functional foods.

Conflicts of Interest: The authors declare no conflict of interest.

\section{References}

1. Halbrecq, B.; Romedenn, P.; Ledent, J.F. Evolution of flowering, ripening and seed set in buckwheat (Fagopyrum esculentum Moench): Quantitative analysis. Eur. J. Agron. 2005, 23, 209-224. [CrossRef]

2. Popovic, V.; Sikora, V.; Ikanovic, J.; Rajicic, V.; Maksimovic, L.; Katanski, S. Production, productivity and quality of buckwheat in organic growing systems in course environmental protection. In Environment Protection of Urban and Suburban Settlement: Proceedings: 17th International Eco-Conference; Novi Sad, Serbia, 25-28 September 2013, Ecological Movement of Novi Sad: Novi Sad, Serbia, 2013; pp. 395-404.

3. Popovic, V.; Sikora, V.; Ugrenovic, V.; Filipovic, V. Status of buckwheat (Fagopyrum esculentum) production in the worldwide and in the Republic of Serbia. In Rural Communities in the Global Economy: Beyond the Classical Rural Economy Paradigms; Istudor, N., de Los Ríos, I., Andrei, J.V., Eds.; Nova Science Publishers: Hauppauge, NY, USA, 2017; pp. 1-400.

4. Popović, V.; Jovović, Z.; Vucković, S.; Ignjatov, M.; Živanović, L.J.; Kolarić, L.J.; Ikanović, J. Significance and application of gluten-free buckwheat pseudograin-Fagopyrum esculentum Moench. In Proceedings of the X Symposium with International Participation Innovations in Field and Vegetable Production, Zemun-Belgrade, Serbia, 21-22 October 2021; pp. 64-65.

5. Glamočlija, Đ.; Janković, S.; Popović, V.; Filipović, V.; Kuzevski, J.; Ugrenović, V. Alternative Crop Species in Conventional and Organic Cultivation System. Alternativne Ratarske Vrste u Konvencionalnom i Organskom Sistemu Gajenja. Monograph: Belgrade, Serbia, 2015; pp. 1-350. ISBN 978-86-81689-32-5. (In Serbian)

6. Chlopicka, J.; Pasko, P.; Gorinstein, S.; Jedryas, A.; Zagrodzki, P. Total phenolic and total flavonoid content, antioxidant activity and sensory evaluation of pseudocereal breads. LWT Food Sci. Technol. 2012, 46, 548-555. [CrossRef] 
7. Ikanović, J.; Rakić, S.; Popović, V.; Janković, S.; Glamočlija, Đ.; Kuzevski, J. Agro-ecological conditions and morpho-productive properties of buckwheat. Biotechnol. Anim. Husb. 2012, 29, 555-562. [CrossRef]

8. Podolska, G. Chapter 22-The effect of habitat conditions and agrotechnical factors on the nutritional value of buckwheat. In Molecular Breeding and Nutritional Aspects of Buckwheat; Zhou, M., Kreft, I., Woo, S.-H., Chrungoo, N., Wieslander, G., Eds.; Academic Press: Cambridge, MA, USA, 2016; pp. 283-297.

9. Fabjan, N.; Rode, J.; Košir, I.J.; Wang, Z.; Zhang, Z.; Kreft, I. Tartary buckwheat (Fagopyrum tataricum Gaertn.) as a source of dietary rutin and quercitrin. J. Agric. Food Chem. 2003, 51, 6452-6455. [CrossRef] [PubMed]

10. Popp, J.; Pető, K.; Nagy, J. Pesticide productivity and food security. A review. Agron. Sustain. Dev. 2013, 33, 243-255. [CrossRef]

11. Skrabanja, V.; Kreft, I.; Go-Lob, T.; Modic, M.; Ikeda, S.; Ikeda, K.; Kreft, S.; Bona-Faccia, G.; Knapp, M.; Kosmelj, K. Nutrient content in buckwheat milling fractions. Cereal Chem. 2004, 81, 172-176. [CrossRef]

12. Stempinska, K.; Soral-Smietana, M. Chemical components and assessment of physicochemical granuloma buckwheat-Shows a comparison of three Polish varieties. Food Sci. Technol. Qual. 2006, 13 (Suppl. S1), 348-357. (In Polish)

13. Bonafaccia, G.; Marocchini, M.; Kreft, I. Composition and technological properties of the flour and bran from common and tartary buckwheat. Food Chem. 2003, 80, 9-15. [CrossRef]

14. Shamsi, K. Effect of planting date and density on the yield and yield components of milk thistle (Silybum marianum L.). J. Appl. Biosci. 2009, 16, 862-863.

15. Zhang, X.; Chai, Y.; Shang, A.J. Effects of seeding date on grain protein content and composition of buckwheat. Fagopyrum 2001, $1,11-13$.

16. Terzić, D.; Popović, V.; Malić, N.; Ikanović, J.; Rajičić, V.; Popović, S.; Lončar, M.; Lončarević, V. Effects of long-term fertilization on yield of siderates and organic matter content of soil in the process of recultivation. J. Anim. Plant Sci. 2019, $29,790-795$.

17. Lalevic, D.; Biberdžić, M.; Ilić, Z.; Milenković, L.; Tmušić, N.; Stojiljković, J. Effect of cultivar and increased nitrogen quantities on some productive traits of triticale. Agric. For. 2019, 65, 127-136. [CrossRef]

18. Rajicic, V.; Milivojević, J.; Popović, V.; Branković, S.; Đurić, N.; Perišić, V.; Terzić, D. Winter wheat yield and quality depending on the level of nitrogen, phosphorus and potassium fertilization. Agric. For. 2019, 65, 79-88. [CrossRef]

19. Popovic, V.; Kolarić, L.J.; Žarković, B.; Živanović, L.J.; Šarčević-Todosijević, L.J.; Golijan, J. Improvement of buckwheat production-Fagopyrum esculentum Moench. In Symposium on Genetics and Plant Breeding in Cereals: 100th Birth Anniversary of Academician Slavko Borojević (1919-2019); Institut za Ratarstvo i Povrtarstvo: Novi Sad, Serbia, 2019; p. 14; ISBN 978-86-80417-83-7. Available online: www.ifvcns.rs/abstracts-borojevic (accessed on 17 November 2021).

20. Kolaric, L.J.; Žarković, B.; Ikanović, J.; Šarčević-Todosijević, L.J.; Popović, V.; Rakašćan, N.; Živanović, L.J. Buckwheat productivity under different agroecological conditions depending on the shape of the vegetation area and the amount of NPK nutrients. In Proceedings of the Conference on Biotechnology, Čačak, Serbia, 15-16 March 2019; Volume 24, pp. 121-126.

21. Nozinic, M. Influence of row spacing on buckwheat yield and quality. Sel. Semen. 2009, 15, 53-62.

22. Biberdzic, M.; Barac, S.; Lalevic, D.; Djikic, A.; Prodanovic, D.; Rajicic, V. Influence of soil tillage system on soil compaction and winter wheat yield. Chil. J. Agric. Res. 2020, 80, 80-89. [CrossRef]

23. Popović, V.; Vučković, S.; Jovović, Z.; Ljubičić, N.; Kostić, M.; Rakaščan, N.; Glamočlija-Mladenović, M.; Ikanović, J. Genotype by year interaction effects on soybean morpho-productive traits and biogas production. Genetika-Belgrade 2020, 52, 1055-1073. [CrossRef]

24. Milanović, T.; Popović, V.; Vučković, S.; Popović, S.; Rakaščan, N.; Petković, Z. Analysis of soybean production and biogas yield to improve eco-marketing and circular economy. Econ. Agric. Belgrade 2020, 67, 141-156. [CrossRef]

25. Jovovic, Z.; Dolijanovic, Z.; Spalevic, V.; Dudic, B.; Przulj, N.; Velimirovic, A.; Popovic, V. Effects of Liming and Nutrient Management on Yield and Other Parameters of Potato Productivity on Acid Soils in Montenegro. Agronomy 2021, 11, 980. [CrossRef]

26. Popovic, V.; Ljubičić, N.; Kostić, M.; Radulović, M.; Blagojević, D.; Ugrenovic, V.; Popovic, D.; Ivosevic, B. Genotype x Environment Interaction for Wheat Yield Traits Suitable for Selection in Different Seed Priming Conditions. Plants 2020, 9, 1804. [CrossRef] [PubMed]

27. Janković, S.; Popović, V.; Rakić, S.; Simić, D.; Alkhammas, A.O.; Rakić, R.; Stanković, S. Influence of nutrition on productivity and chemical composition of Khorasan wheat-Triticum turgidum L. Ssp. turanicum Jakubz. Agric. For. 2020, 66, 113-124. [CrossRef]

28. Ljubičić, N.; Popović, V.; Ćirić, V.; Kostić, M.; Ivošević, B.; Popović, D.; Pandžić, M.; Seddiq, E.L.M.; Janković, S. Multivariate Interaction Analysis of Winter Wheat Grown in Environment of Limited Soil Conditions. Plants 2021, 10, 604. [CrossRef] [PubMed]

29. Dražić, N.; Rakaščan, N.; Radojević, V.; Popović, D.; Ikanović, J.; Popovic, V.; Petkovic, Z. Cereals as energy sources in the function of circular economy. Agric. For. 2021, 67, 159-169.

30. Rajičić, V.; Popović, V.; Perišić, V.; Biberđžić, M.; Jovović, Z.; Gudžić, N.; Mihailović, V.; Čolić, V.; Đurić, N.; Terzić, D. Impact of Nitrogen and Phosphorus on Grain Yield in Winter Triticale Grown on Degraded Vertisol. Agronomy 2020, 10, 757. [CrossRef]

31. Rakaščan, N.; Dražić, G.; Popović, V.; Milovanović, J.; Živanović, L.; Remiković-Aćimić, M.; Milanović, T.; Ikanović, J. Effect of digestate from anaerobic digestion on Sorghum bicolor L. production and circular economy. Not. Bot. Horti Agrobot. Cluj Napoca 2021, 49, 1-13. [CrossRef]

32. Maksimović, L.; Popović, V.; Stevanović, P. Water and irrigation requirements of field crops grown in central Vojvodina, Serbia. Agric. For. 2018, 64, 133-144. [CrossRef] 
33. FAO. Faostat FAO Statistics Division; FAO: Rome, Italy, 2020.

34. Hulihalli, U.K.; Shantveerayya, I. Effect of planting geometry and nutrient levels on the productivity of buckwheat. Int. J. Curr. Microbiol. Appl. Sci. 2018, 7, 3369-3377. [CrossRef]

35. Vreva, M.; Zečević, V.; Balijagić, J.; Jovančević, M.; Arslanović, S.; Fetić, E. The influence of locality and variety on the yield of organically grown buckwheat (Fagopyrum esculentum). Agroznanje 2012, 13, 317-324.

36. Popović, V.; Malešević, M.; Miladinović, J.; Marić, V.; Živanović, L.J. Effect of agroecological factors on variations in yield, protein and oil contents in soybean grain. Rom. Agric. Res. 2013, 30, 241-247.

37. Martínez, I.; Ovalle, C.; Del Pozo, A.; Uribe, H.; Valderrama, N.; Prat, C. Influence of conservation tillage and soil water content on crop yield in dry land compacted Alfisol of central Chile. Chil. J. Agric. Res. 2011, 71, 615-622. [CrossRef]

38. Salehi, A.; Mehdi, B.; Fallah, S.; Kaul, H.P.; Neugschwandtner, R.W. Integrated fertilization of buckwheat-fenugreek intercrops improves productivity and nutrient use efficiency. Nutr. Cycl. Agroecosyst. 2018, 110, 407-425. [CrossRef]

39. Xiang, D.B.; Gang, Z.; Wan, Y.; Tan, M.L.; Song, C.; Song, Y. Effect of planting density on lodging-related morphology, lodging rate, and yield of tartary buckwheat (Fagopyrum tataricum). Plant Prod. Sci. 2016, 19, 479-488. [CrossRef]

40. Arshad, M.; Bakhsh, A.; Ghafoor, A. Path coefficient analysis in chickpea (Cicer arietinum L.) under rainfed conditions. Pak. J. Bot. 2004, 36, 75-81.

41. Sobhani, M.R.; Rahmikhdoev, G.; Mazaheri, D.; Majidian, M. The effect of sowing date, pattern of planting and nitrogen on quantitative and qualitative yield in summer sowing buckwheat (Fagopyrum esculentum Moench). Adv. Environ. Biol. 2012, 6 , 440-446.

42. Özyazici, G. Effect of Nitrogenous Fertilizer Doses on Seed Yield and Some Agricultural Properties of Buckwheat (Fagopyrum esculentum Moench.) Plant. ISPEC J. Agric. Sci. 2020, 4, 635-648. [CrossRef]

43. Yokozawa, T.; Kim, H.Y.; Nonaka, G.; Kosuna, K. Buckwheat extract inhibit progression of renal failure. J. Agric. Food Chem. 2002, 50, 3341-3345. [CrossRef] [PubMed]

44. Oomah, B.; Mazza, G. Flavonoids and antioxidative activities in buckwheat. J. Agric. Food Chern. 1996, 44, 1746-1750. [CrossRef]

45. Schilcher, H.; Patz, B.; Schimmel, K.C.H. Klinische Studie mit einem Phytopharmakon zur Behandlung von Mikrozirkulationsstorungen. Arztez. Naturheilverfahren 1990, 31, 819-826. (In German)

46. Sobhani, M.; Farnia, A.; Mazaheri, D.; Majidian, M. Effects of Sowing Date, Planting Pattern and Nitrogen Levels on Leaf and Flower Essential Oil, Yield and Component Yield Grain of Buckwheat (Fagopyroum esculentum Moench). Iran. J. Field Crops Res. 2017, 15, 477-493. [CrossRef]

47. Wagenbreth, D.; Hagels, H.; Schilcher, H. Characterisation of buckwheat cultivars and gene bank material for rutin content and growth parameters. In Proceedings of the International Symposium Breeding Research on Medicinal and Aromatic Plants, Quedlimburg, Germany, 11 October 1996; pp. 95-102.

48. Janovská, D.; Jágr, M.; Svoboda, P.; Dvořáček, V.; Meglič, V.; Hlásná Čepková, P. Breeding Buckwheat for Nutritional Quality in the Czech Republic. Plants 2021, 10, 1262. [CrossRef] [PubMed]

49. Popovic, V.; Vidic, M.; Jockovic, D.J.; Ikanovic, J.; Jaksic, S.; Cvijanović, G. Variability and correlations between yield components of soybean [Glycine max (L.) Merr.]. Genetika-Belgrade 2012, 44, 33-45. [CrossRef]

50. Jiang, Y.; Wang, X.; Zeng, Z.; Han, J.; Schiavon, M.; Tang, C.; Lu, G.; Lei, Y.; Li, J.; Hu, Y.; et al. Performance of common buckwheat (Fagopyrum esculentum M.) in response to row spacing under ridge and furrow cropping systems in a semiarid region of China. Arch. Agron. Soil Sci. 2018, 64, 1807-1817. [CrossRef]

51. Sobhani, M.R.; Rahmikhdoev, G.; Mazaheri, D.; Majidian, M. Influence of different sowing date and planting pattern and N rate on buckwheat yield and its quality. Aust. J. Crop Sci. 2014, 8, 1402-1414.

52. Zhang, Z.L.; Zhou, M.L.; Tang, Y.; Li, F.L.; Tang, Y.X.; Shao, J.R.; Xue, W.T.; Wu, Y.M. Bioactive compounds in functional buckwheat food. Food Res. Int. 2012, 49, 389-395. [CrossRef] 